\title{
Dalechampia L. (Euphorbiaceae) in the Brazilian Amazon
}

\author{
Jone Clebson Ribeiro Mendes ${ }^{\circledR}$, Alessandro Silva do Rosário ${ }^{2}$, Narcísio C. Bigio ${ }^{3}$, Rafaela Alves Pereira-Silva \\ \& Ricardo de S. Secco 5 \\ ${ }^{1}$ Universidade Federal Rural da Amazônia, Museu Paraense Emílio Goeldi, Programa de Pós-Graduação em \\ Ciências Biológicas - Botânica Tropical, CEP 66077-830, Belém, PA, Brasil. \\ ${ }^{2}$ Universidade do Estado do Pará, 66050-540, Belém, PA, Brasil. \\ ${ }^{3}$ Universidade Federal de Rondonia, CEP 76801-059, Porto Velho, RO, Brasil. \\ ${ }^{4}$ Universidade Federal Rural de Pernambuco, Programa de Pós-Graduação em Botânica, CEP 52171-900, \\ Recife, PE, Brasil. \\ ${ }^{5}$ Museu Paraense Emílio Goeldi, CEP 66077-830, Belém, PA, Brasil. \\ *Corresponding author: jonecmendes5@gmail.com
}

MENDES, J.C.R., ROSÁRIO, A.S., BIGIO, N.C., PEREIRA-SILVA, R.A., SECCO, R.S., Dalechampia L. (Euphorbiaceae) in the Brazilian Amazon. Biota Neotropica 21(4): e20201010. https://doi.org/10.1590/16760611-BN-2020-1010.

\begin{abstract}
A taxonomic treatment of Dalechampia species found in the Brazilian Amazon is presented. The study was based on an analysis of herbarium material (including historical and type collections), specimens collected in the field, and literature. Twenty-three species, distributed in five sections, are recognized. Dalechampia hastata is endemic to the Brazilian Amazon. Among the species surveyed, thirteen species are considered to be Least Concern (LC), and not currently at risk of extinction. Six species (D. attenuistylus, D. brownsbergensis, D. fragrans, D. hastata, D. megacarpa and D. olympiana) are Endangered (EN), three species (D. gentryi, D. heterobractea and D. tenuiramea) are Near Threatened (NT), and D. liesneri is listed with Deficient Data (DD). If we consider the occurrence only in Brazil of three species, the taxa can be designated as Vulnerable (VU). Dalechampia micrantha and $D$. parvibracteata are lectotypified. The lectotype of $D$. cissifolia, D. juruana, and D. pernambucensis is clarified. New occurrences are reported for some countries. An identification key, descriptions, taxonomic comments, illustrations, the conservation status, phenological data, and geographic distribution maps are provided.

Keywords: Acalyphoideae; Amazonian Flora; Dalechampiinae; Conservation status; Taxonomy.
\end{abstract}

\section{Dalechampia L. (Euphorbiaceae) na Amazônia brasileira}

Resumo: Um tratamento taxonômico das espécies de Dalechampia encontradas na Amazônia brasileira é apresentado. $\mathrm{O}$ estudo foi baseado na análise de materiais de herbário (incluindo coleções históricas e tipos), espécimes coletados durante o trabalho de campo, além de documentação bibliográfica. Foram reconhecidas 23 espécies, distribuídas em cinco seções. Dalechampia hastata é endêmica da Amazônia brasileira. Entre as espécies pesquisadas, treze espécies são consideradas Menos Preocupante (LC) e não estão atualmente em risco de extinção. Seis espécies (D. attenuistylus, D. brownsbergensis, D. fragrans, D. hastata, D. megacarpa e D. olympiana) estão Em Perigo (EN), três espécies (D. gentryi, D. heterobractea e D. tenuiramea) estão Quase Ameaçada (NT), e D. liesneri está listada com Dados Deficientes (DD). Se considerarmos a ocorrência apenas no Brasil de três espécies (D. cissifolia, D. dioscoreifolia e D. juruana) os táxons podem ser designados como Vulneráveis (VU). Dalechampia micrantha e D. parvibracteata são aqui lectotipificados. Aqui é esclarecida a lectotipificação de $D$. cissifolia, D. juruana e D. pernambucensis. É reportada novas ocorrências para alguns países. São apresentadas chave de identificação, descrições, comentários taxonômicos, ilustrações, status de conservação, dados fenológicos e mapas de distribuição geográfica.

Palavras-chave: Acalyphoideae; Dalechampiinae; Flora Amazônica; Status de conservação; Taxonomia. 


\section{Introduction}

Dalechampia L. (Euphorbiaceae) belongs to the subfamily Acalyphoideae Beilschm., tribe Plukenetieae (Benth.) Hutch. (Müller 1866, Pax \& Hoffmann 1919), and it is the only genus in subtribe Dalechampiinae (Müll. Arg.) G.L. Webster (Webster 1994, 2014), which is classified into six sections and approximately 130 species with Pantropical distribution (Webster \& Armbruster 1991, Govaerts et al. 2018). In Brazil, there are more than 72 species and 48 are endemic (Pereira-Silva et al. 2020a). These species are climbing plants, or rarely shrubs, which grow in humid forests, as well as in the Caatinga and Cerrado (Webster \& Armbruster 1991, Pereira-Silva et al. 2020a) and disturbed areas, such as forest margins and clearings (São-Thiago \& Vieira 2007).

Dalechampia has a peculiar morphological characteristic within Euphorbiaceae that is a specialized pseudanthium inflorescence. The pseudanthium comprises pistillate and staminate flowers surrounded by two, usually colored bracts, which contribute to insect pollination strategies, and the staminate flowers have a secretory gland with resin that is collected by female bees of tribes Euglossini and Meliponini in family Megachilidae (Webster \& Webster 1972, Armbruster \& Webster 1979, Armbruster \& Steiner 1992, Armbruster \& Baldwin 1998, Webster \& Armbruster 1991). The type of pseudanthium in section Rhopalostylis (Klotzsch) Pax \& K. Hoff. differs from that of other species in the genus because it is nearly inconspicuous and lacks the resiniferous gland (Armbruster 1996).

The most extensive treatments of Dalechampia were made by Müller (1874) and Pax \& Hoffmann (1919), who cited 47 and 88 species respectively, and more recently, the synopsis elaborated by Webster and Armbruster (1991) for neotropical species, which still represents the most critical work for the taxon. In Brazil, studies addressing the Dalechampia taxonomy in recent years have advanced exponentially, such as local floras (e.g., Maia et al. 2002; Rodrigues 2007; PereiraSilva et al. 2020b, c; Mendes et al. 2020), new species described (e.g., Cordeiro 1998; Pereira-Silva et al. 2016, 2019), rediscovered (Silva et al. 2020), as well as nomenclatural studies (Mendes et al. 2019; AthiêSouza et al. 2019).

However, morphological studies focused on Dalechampia species in the Brazilian Amazon are non-existent. Although it highlights general morphological aspects of taxa, the treatment by Webster and Armbruster (1991) does not provide descriptions or illustrations of many species, nor mention most of the analyzed collections, especially material collected in the Brazilian Amazon. This reflects the importance of carrying out this work for the region. The Amazon Biome has the most significant tropical forest remaining on the planet and stands out as the primary source of neotropical diversity (Antonelli et al. 2018), with the number of plant species being underestimated for this region, with estimates varying from 50,000 (e.g., Hubbell et al. 2008) to substantially lower (e.g., Silman 2007).

In addition, it was verified that the species of Dalechampia from the Brazilian Amazon have not been updated and that they are represented by numerous undetermined or misidentified specimens in Amazonian herbaria. Further, part of this material consists of incomplete (depauperated) or sterile specimens. Considering the representativeness of Dalechampia in the Brazilian Amazon and the scarcity of clarifying taxonomic studies about this subject, the present work had the objectives of creating a taxonomic treatment, and updating information about the morphology and distribution of the species of Dalechampia in this region. An identification key, descriptions, taxonomic comments, illustrations, the conservation status, phenological data, and geographic distribution maps are provided.

\section{Material and Methods}

\section{Study area}

The Amazon biome (Figure 1) is home to the largest tropical forest in the world with $4,196,943$ million $\mathrm{km}^{2}$, occupying $49.29 \%$ of the Brazilian territory (IBGE 2004, MMA 2021), formed by 9 regions (Prance 1994) and the rest divided among the countries of Bolivia, Colombia, Guyana, Peru and Venezuela (Becker 2004). The prevailing climate in the region is humid equatorial, characterized by high temperatures and large amounts of rainfall throughout the year, resulting in a considerable interdependence between climate and vegetation (Ducke \& Black 1954). The local vegetation is mainly represented by upland forests (Terra Firme), forests of flooded areas (Varzea and Igapó Forest), savannas, campinarana (white sand vegetation), as well as specialized vegetation (for a complete characterization of the area, see Pires \& Prance 1985; Figures 1A-M), with a strong influence of the surrounding areas, such as the crystalline shields of Guyana and Brazil on the north and south of the Amazon River Basin (Prance 1978).

\section{Taxonomic treatment}

The study is mainly based on material archived at the following national and international herbaria (ALA, BHCB, F, G, HAMAB, HUEFS, HRB, IAN, INPA, K, MFS, MG, MICH, MIRR, MY, MO, NY, P, R, RB, RON, S, SP, UFACPZ, UFG, UFMT, US and VEM; acronyms according to Thiers 2020, continuously updated). Some fieldwork was also conducted to collect material in situ, in the states of Amapá, Amazonas, Pará, and Rondônia. The collections were processed according to standard procedures (Mori et al. 1989) and archived at IAN, MG and RON.

The identification of the species was based on protologues of the Baillon (1858), Müller (1866, 1874), Pax and Hoffmann (1919), Armbruster and Webster (1991) available on the site Biodiversity Heritage Library (https://www.biodiversitylibrary.org/). Comparisons with historical collections and type specimens that were mostly viewed as images on the site JSTOR Global Plants (https://plants.jstor. org/), and diagnoses and descriptions in the literature (Armbruster \& Webster 1991). The vegetative and reproductive parts were examined and measured using a ZEISS stereomicroscope coupled to the clear chamber. The descriptive terminology was based on Baillon (1858), Müller (1866, 1874), Pax and Hoffmann (1919), Armbruster and Webster (1991) and complemented by Radford et al. (1974) and Harris and Harris (2001). The abbreviations of the names of the works where the species were published follow Brummit and Powell (1992), while the names of authors follow the International Plant Names Index - IPNI (https://www.ipni.org/).

The information about occurrence sites, flowering and fruiting periods, and geographical distribution were based on field observations, data taken from the labels of examined specimens, previously mentioned literature, and Flora of Brazil 2020 (http://floradobrasil.jbrj.gov.br/; Pereira-Silva et al. 2020a). The typification of the species was based on the International Code of Nomenclature for Algae, Fungi, and 

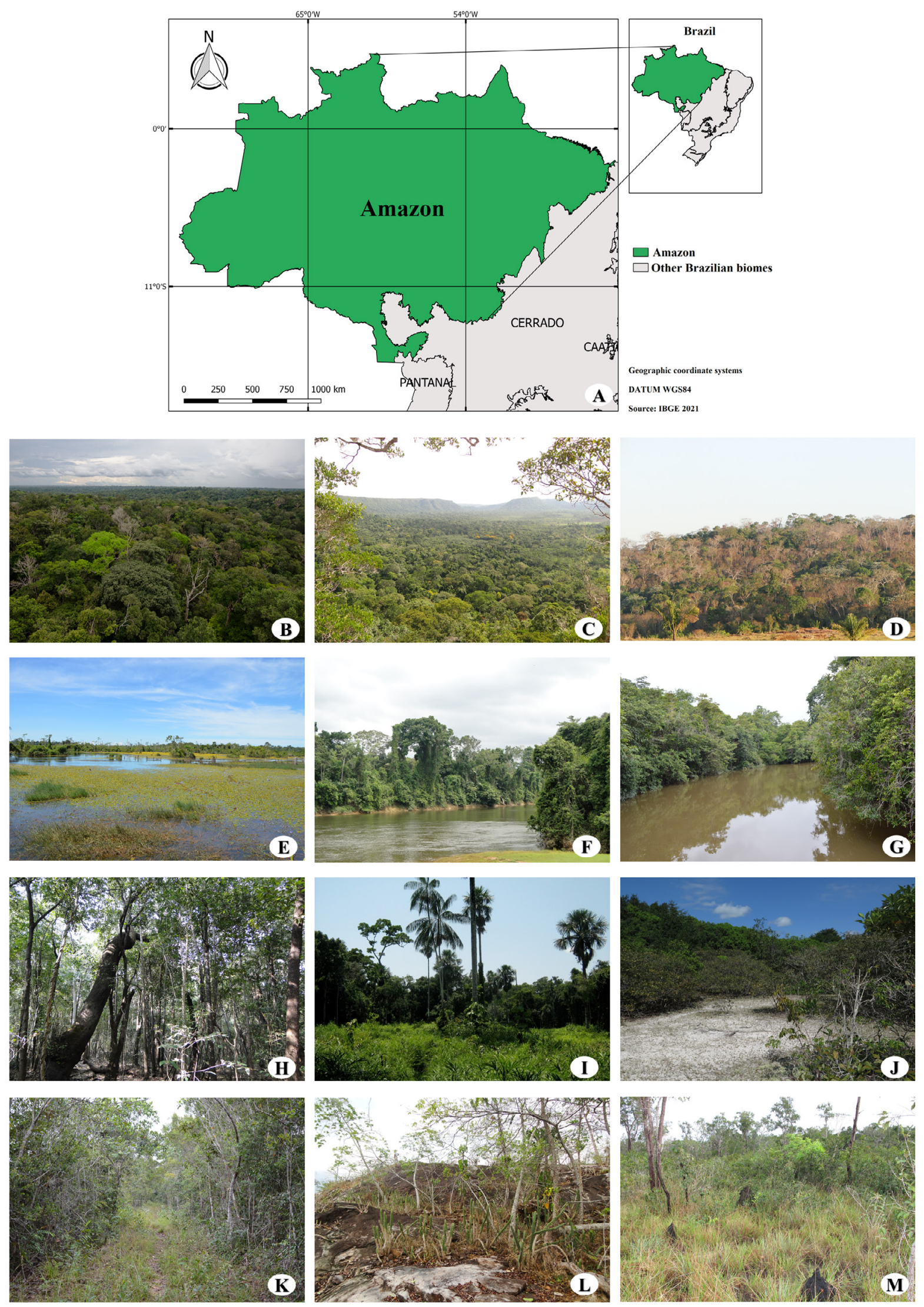

Figure 1. Map of the Amazon biome and characterization of the Amazonian physiognomies: A) Map of Amazon Biome; B) Dense Ombrophilous Forest

(Dense Terra Firme Forest); C) Open Ombrophylous Forest ( Open Terra Firme Forest); D) Semideciduous Seasonal Forest; E) Igapó (Flood Season); F) Alluvial Ombrophilous Forest (Igapó Forest); G) Alluvial Ombrophilous Forest (Varzea Forest in flood season); H) Alluvial Ombrophilous Forest (Varzea Forest in dry season); I) Open Forest with Bamboo; J) Shrubby Campinarana; K) Forested Campinarana; L) Rocky Outcrop; M) Amazonian Savannah. 
Plants (Turland et al. 2018, hereafter ICN). The distribution map was made using the software QGIS 2.18 (QGIS Development Team 2019). For the conservation status, we used data from GBIF to get the global assessment (S1), and the Geospatial Conservation Assessment Tool (GEOCAT) (Bachman et al. 2011) with a cell grid of $2 \mathrm{~km}^{2}$, provided information about the area of occupancy and the extent of occurrence for species that occur in Brazilian Amazon. The conservation status was evaluated following the Red List criteria of the International Union for the Conservation of Nature (IUCN 2019).

\section{Taxonomic treatment}

Dalechampia L., Sp. P1. 2: 1054. 1753. Type: Dalechampia scandens $\mathrm{L}$.

Twining vine or erect subshrub, monoecious, trichomes simple or stinging. Leaves alternate, simple or compound, petiolate, with stiples at the base of the leaf blade; leaf blade unlobed, 3-lobed or 3-palmately parted, margin entire to slightly serrate, dentate, sometimes with glandular trichomes; venation pinnate, actinodromous, campylodromous or eucamptodromous. Inflorescence a pseudanthium, bisexual, axillary, rarely terminal; with 2-4 pairs of stipules at base; subtended by 2 involucral bracts, these generally showy (greenish, white, pink, purplish or yellow), ovate or oblong, unlobed to deeply 3-lobed or 3-toothed; margins entire, dentate or lacerate. Staminate pleiochasium subtended by 2-4 bracteoles, with 5-13 flowers; set of resinous or odoriferous glands consisting of laminar, fimbriate or laminar-glandular subunits present or absent. Pistillate cymule subtended by 1-3 bracteoles, 3 -flowered, centrally located. Staminate flowers apetalous, pedicellate; sepals 4-6, free, valvate, lanceolate; stamens 5-93, filaments joined into a column, anthers with longitudinal dehiscence. Pistillate flowers apetalous, pedicellate; sepals 4-11, free, entire, pinnatisect or pinnatifid; ovary, 3-locular, 3-carpelate, 1 ovule per locule; stylar column elongate, stigma tip often dilated. Capsule schizocarpic, with explosive dehiscence, more or less woody, with stylar column, sepals and involucral bracts usually persistent. Seeds globose or subglobose, ecarunculate.

\section{Key to Dalechampia species in the Brazilian Amazon}

1.Leaf blades compound, 3-foliolate 2. Leaf blades chartaceous; pseudanthium with 2 bracteal stipules; staminate flowers with 2 bracteoles; peduncle subsessile in pistillate cymule ................................................ D. cissifolia 2. Leaf blade membranaceous; pseudanthium with 4 bracteal stipules; staminate flowers with 4 bracteoles; peduncle $>1 \mathrm{~mm}$ in pistillate cymule

3. Leaf blade with sparsely denticulate to sinuate margin, adaxial surface glabrous; involucral bracts white, pubescent in adaxial surface; capsule glabrous D. triphylla

3. Leaf blade with serrate-ciliate margin, adaxial surface pubescent or slightly hirsutous; involucral bracts greenish, glabrous on adaxial surface; capsule pilose

4. Petiole 5.5-13 cm long, tomentose; involucral bracts $1-1.3 \times 0.8-1$ $\mathrm{cm}$, obdeltoid; pistillate sepals pinnatifid-laciniate; apex of stylar column slightly enlarged-clavate .......................... juruana 4. Petiole 1-5 cm long, hirsutous; involucral bracts 3-5 $53.5-7.2 \mathrm{~cm}$, widely obovate; pistillate sepals entire; apex of stylar column slightly dilated-obovate D. sylvestris
1. Leaf simple, unlobed to 3-lobed ................................ 5 5. Erect subshrubs, blade base cuneate, venation camptodromous, primary veins 1; stipels absent; involucral bracts pink D. magnoliifolia

5. Twining vine; blade base cordate, hastate, round or truncate, venation actinodromous, campylodromous or eucamptodromous, primary veins 3 to 7; stipels present; involucral bracts cream, white or green (pale pinkish in D. dioscoreifolia and purplish in D. cujabensis) .............. 6 6. Leaf blade glabrous on both surfaces ............................................. 7 7. Petiolar stipules ovate, deciduous; involucral bracts margin entire; staminate pleiochasium 12 (-13)-flowered, glabrous

D. fragrans

7. Petiolar stipules lanceolate, persistent; involucral bracts margin denticulate or slightly serrate; staminate pleiochasium 8-9-flowered, pilose ...........

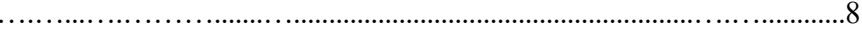
8. Involucral bracts stipuliform, base truncate, primary veins 3; resiniferous glands absent; seeds rugose .................. D. liesneri 8. Involucral bracts triangular-ovate, base cordate to subcordate, primary veins 5; resiniferous glands laminar; seeds smooth......... D. tenuiramea 6. Leaf blade pilose at least on one surface ........................... 9 9. Involucral bracts apex 3-lobed or 3-toothed …............................. 10 10. Leaf venation eucamptodromous; involucral bracts creamy white; resiniferous glands fimbriate

D. tiliifolia

10. Leaf venation actinodromous or campylodromous; involucral bracts green or purplish; resiniferous glands laminar or punctiform

.11

11. Petiolar stipules deciduous; leaf blade with adaxial surface glabrous; involucral bracts purplish; staminate sepals $\geq 6$; stamens $\geq 80$

D. cujabensis

11. Petiolar stipules persistent; leaf blade with adaxial surface pilose; involucral bracts green; staminate sepals $\leq 5$; stamens $\leq 50 \ldots \ldots \ldots \ldots$.

12

12. Leaf blade $10-20 \times 10-25 \mathrm{~cm}$, base deeply cordate, margin serrate, abaxial surface copiously pubescent, chartaceous, campylodromous; involucral bracts primary veins $9(-11)$

D. brownbergensis

12. Leaf blade $2.5-14 \times 3-11 \mathrm{~cm}$, base cordate, margin entire, abaxial surface sparsely pilose, membranaceous, actinodromous; involucral

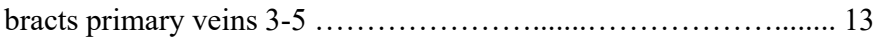
13. Bracteal stipules deltoid; involucral bracts with margins fimbriateciliate, with stipitate glandular trichomes; stigma tip of stylar column peltate to discoid D. pernambucensis 13. Bracteal stipules lanceolate; involucral bracts with margins serrateciliate, with or without sparse stipitate glandular trichomes; stigma tip of stylar column slightly crateriform

D. scandens 9. Involucral bracts apex entire (acute to acuminate)

14. Leaf glabrous on abaxial surface; involucral bracts margin revolute; seed flattened-oval 9-11 mm diam.

D. megacarpa

14. Leaf pilose on abaxial surface; involucral bracts margin flat; seed subspherical or globose $0.6-5 \mathrm{~mm}$ diam. ...................... 15 15. Involucral bracts conspicuous ( $\geq 30 \mathrm{~mm}$ long); resiniferous gland present; pistillate sepals pinnatifid or pinnatisect-lacinulate ............ 16. Leaf blade ovate, deeply cordate, chartaceous, campylodromous; involucral bracts pale pinkish, abaxial surface glabrous; staminate 
bracteoles 4; resiniferous gland secreting brownish-brown resin D. dioscoreifolia 16. Leaf blade triangular-ovate, cordate, membranaceous, actinodromous; involucral bracts white cream, abaxial surface pubescent; staminate bracteoles 3; resiniferous gland secreting yellowish resin D. affinis 15. Involucral bracts inconspicuous ( $\leq 16 \mathrm{~mm}$ long); resiniferous gland absent; pistillate sepals entire . 17 17. Leaf blade membranaceous; involucral bracts subcordate; bracteal stipules $\leq 1.5 \mathrm{~mm}$ long . .. 18 18. Petiolar stipules deciduous; abaxial surface of leaf blade lanuginous, blade nerves $3(-5)$, stipels inconspicuous (0.1-0.2 mm long); pseudanthium peduncle subsessile; adaxial surface of involucral bracts glabrous .................................................. D. olympiana 18. Petiolar stipules persistent; abaxial surface of leaf blade pubescent; blade nerves 5(-7), stipels conspicuous (0.5-1 mm long); pseudanthium peduncle $9.5-10 \mathrm{~cm}$; adaxial surface of involucral bracts densely pubescent

D. parvibracteata 17.Leafbladechartaceous; involucral bractscuneate, obtuse to rounded; bracteal stipules $\geq 2 \mathrm{~mm}$ long. .. 19 19. Leaf blade lanceolate, or sometimes with 2-3 lateral lobes, base cordate to hastate, venation actinodromous to campylodromous; involucral bracts cream-white; capsule hirsutous

D. hastata 19. Leaf blade ovate or oblong-ovate, base cordate or sub-truncate to rounded, venation campylodromous; involucral bracts green; capsule strigose .................................................... 20

20. Leaf blade oblong-ovate; staminate pleiochasium 13-flowered; staminate bracteoles with margin denticulate; staminate sepals 3 ; pistilate bracteoles 5-6; capsule 0.6-1 $\mathrm{mm}$ diam.

D. micrantha

20. Leaf blade ovate; staminate pleiochasium $\leq 11$-flowered; staminate bracteoles with margin entire; staminate sepals 4; pistilate bracteoles 3 ; capsule $\geq 6 \mathrm{~mm}$ diam. .. 21 21. Petiolar stipules persistent; petiole hirsutous; involucral bracts dimorphic (bottom/proximal $\geq 10 \mathrm{~mm}$ long; upper/distal $\leq 5 \mathrm{~mm}$ long), margin entire; staminate bracteoles $\geq 2 \mathrm{~mm}$ long .

D. heterobractea

21. Petiolar stipules deciduous; petiole strigose; involucral bracts monomorphic, margin glandular serrate; staminate bracteoles $\leq 1.5 \mathrm{~mm}$ long 22. Leaf blade nerves $5(-7)$; involucral bracts $\geq 3-10 \mathrm{~mm}$ long, abaxial surface strigose; involucral bracts primary veins $3(-5)$; bracteal stipules 2; staminate pleiochasium 10-11-flowered; pistillate peduncle sessile; capsule grayish ............................................ D. attenuistylus 22. Leaf blade nerves $3(-5)$; involucral bracts $\leq 3 \mathrm{~mm}$ long, abaxial surface glabrous; involucral bracts primary veins $1-2(-3)$; bracteal stipules 4 ; staminate pleiochasium 8-flowered; pistillate peduncle 4-12 mm long; capsule light-brown

D. gentryi

Dalechampia affinis Müll. Arg., Linnaea 34: 223. 1865. Type: FRENCH GUIANA. Mana: 1856, P.A. Sagot s.n. (lectotype G00209185!, designated by Armbruster and Webster 157: 1991; isolectotype P00712311!).

Figure 2A-D; Figure 3A

Twining vine. Leaves simple, petiolar stipules $2.5-7 \mathrm{~mm}$ long, in pairs, persistent, linear-lanceolate; petiole $1.5-8 \mathrm{~cm}$ long, pubescent;

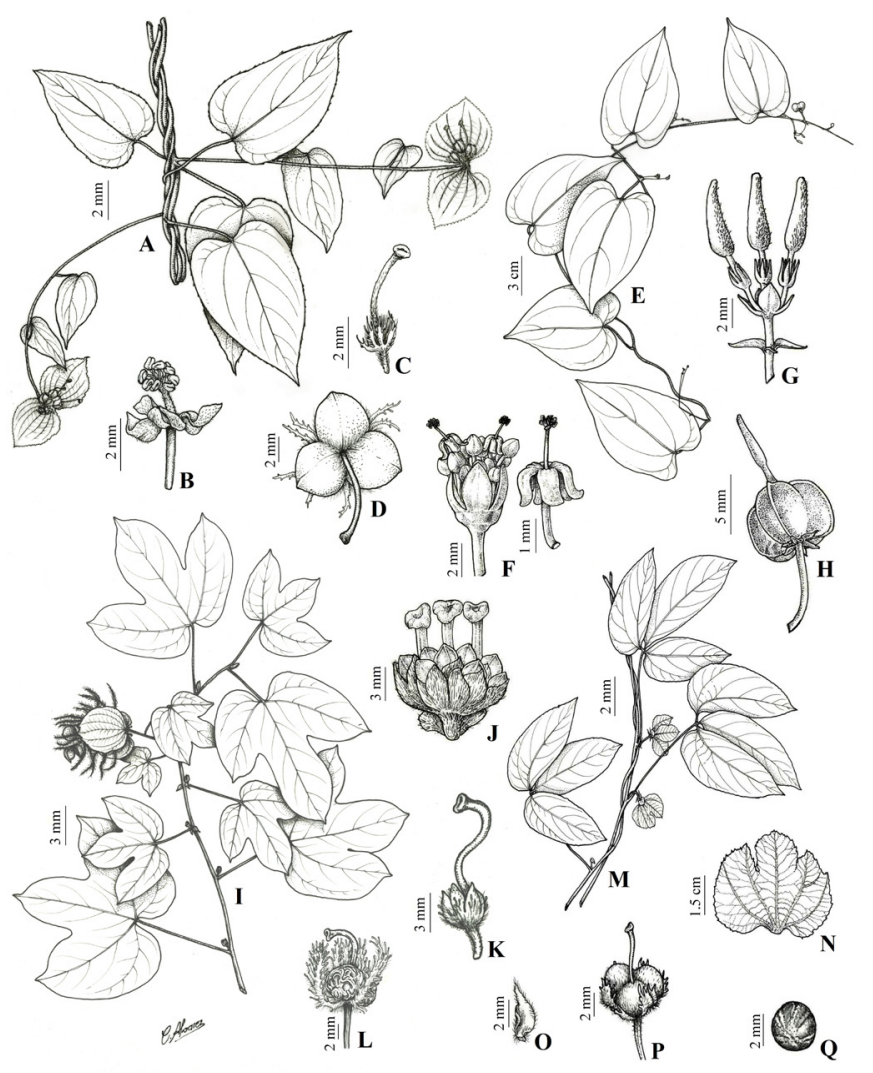

Figure 2-A-D. Dalechampia affinis - A. branch; B. staminate flower; C. pistillate flower; D. fruit with pistillate sepals (A, B, C Snethlage, E. [MG9513], D Chagas, J. 122). E-H. D. attenuistylus - E. branch; F. staminate pleiochasium and staminate flower; G. pistillate cymule; $\mathrm{H}$. fruit (Evandro \& Knowles 1286). I-L. D. brownsbergensis - I. branch; J. staminate pleiochasium with bud, showing wide-punctate bracteoles; K. pistillate flower; L. fruit showing pistillate sepals (Silva, F.A. et al. 281). M-Q. D. cissifolia - M. habit; N. involucral bracts; O. pistillate sepals; P. fruit showing stylar column and persistent pistillate sepals; Q. seed (Prance, G.T. et al. 12380).

leaf blade, unlobed, 4-8 $\times 2.5-9 \mathrm{~cm}$, triangular-ovate, base cordate, apex acutely acuminate, margin slightly denticulate, adaxial surface pubescent, abaxial surface velutinous; membranaceous, venation actinodromous; primary veins $3-5$; stipels $2,1.5-2.5 \mathrm{~mm}$ long, lanceolate, persistent. Pseudanthium terminal or axillary, peduncle $2.5-8 \mathrm{~cm}$ long; involucral bracts $3-5.5 \times 2-4 \mathrm{~cm}$, white-cream, widely ovate, velutinous on adaxial surface, pubescent on abaxial surface, apex acuminate, base obtuse to slightly acute, margin slightly dentate, primary veins 7 (-9); bracteal stipules 2, 3-6 mm long, linear-lanceolate. Staminate pleiochasium 10-12-flowered, peduncle 1-2 mm long, lightly hirsutous; staminate bracteoles 3, 5-6 × 6-7 mm, cuspidate-ovate, free, adaxial and abaxial surfaces glabrous; resiniferous glands 5-6 $\times 6-7$ $\mathrm{mm}$, laminar, with yellowish resin. Staminate flowers, articulated pedicel 2-5 mm long; pedicel 2-2.5 mm long; sepals 5 (-6), 3.5-4 × 0.5-1 $\mathrm{mm}$, lanceolate; stamens $18-40$, staminal tube 3-4 mm long; anthers bithecate, rimose. Pistillate cymule 3-flowered, peduncle $1-1.5 \mathrm{~mm}$ long, pubescent; pistillate bracteoles 3, 4-5 × 2-2.5 mm, obovate, free, adaxial and abaxial surfaces glabrous, margin entire-ciliate. Pistillate flowers, pedicel 1-2 mm long; sepals 10-12, 2-2.5 × 0.5-1 mm, pinnatifid, with sparsely stipitate glands; ovary $2-2.5 \mathrm{~mm}$ diam., hispid, 
stylar column 7-11 mm long, apex umbraculiform-dilated. Capsule 5-8 $\mathrm{mm}$ diam, light brown, sparsely pubescent to densely hispid, with persistent pistillate sepals. Seed $4 \mathrm{~mm}$ diam, globose, smooth, whitish with grayish-brown macules.

Distribution, habitat, and conservation status: Brazil, French Guiana, Guyana, and eastern Venezuela (Webster \& Armbruster 1991). In Brazil, it occurs in the Central-West (Mato Grosso), Southeastern (Minas Gerais), Northeast (Bahia, Maranhão, Piauí), and North (Amazonas, Amapá, Pará, Rondônia, Roraima; Figure 4A) regions (Pereira-Silva et al. 2020a, b). In the study area, this species is frequently found in gallery or ciliary forest, igapó, and terra firme forests, near sea level to $210 \mathrm{~m}$. According to IUCN (2019) criteria, this species is designated as Least Concern (LC), due to its EOO of 5,263,323.776 $\mathrm{km}^{2}$ (see Table 1).

Phenology: Flowers and fruits from January to October (Brazilian Amazon).
Taxonomic Notes: Dalechampia affinis is superficially similar to D. tiliifolia. However, it is easily distinguished by the exclusively unlobed, triangular-ovate leaf blade (vs. unlobed, with a lateral lobe and 3-lobed on the same individual in D. tiliifolia), involucral bracts with acuminate apex (vs. 3-dentate apex), and umbraculiform-dilated (vs. discoid to peltate) stylar column apex.

Selected Material: BRAZIL. AMAZONAS: Novo Airão, Anavilhanas, 324'S, 6551'W, V.1980, fl., fr., M. Goulding 81 (MG); Manaus, Bilhares, $3^{\circ} 06$ 'S, $60^{\circ} 01$ 'W, 21.VII.1955, fl., fr., W.A. Rodrigues (MG21878, INPA1456). AMAPÁ: Macapá, APA da Fazendinha, 004'S, 51 ${ }^{\circ} 07^{\prime}$ W, 31.VII.1983, fl., fr., S. Mori et al. 15723 (MG, NY). PARÁ: Monte Alegre, Maicurú, $1^{\circ} 54^{\prime}$ S, 54º6'W, 21.VII.1908, fl., fr., E. Snethlage (MG9513, RB13520). RONDÔNIA: Porto Velho, MutumParaná, 9³6'S, 6456'W, 1.VII.1968, fl., G.T. Prance et al. 5418 (INPA, MG); Nova Mamoré, 10²7'S, 6441'W, 11.V.2013, fl., N.C. Bigio 1012 (INPA, NY, RB, RON). RORAIMA: Alto Alegre, $3^{\circ} 24^{\prime}$ 'S, $61^{\circ} 26^{\prime} \mathrm{W}$, 12.VI.1986, fl., M.J.G. Hopkins et al. 682 (INPA, MO, NY).

Table 1. Dalechampia species found in the Brazilian Amazon and their respective assessments following IUCN (2019) in their range of distribution.

\begin{tabular}{|c|c|c|c|}
\hline Taxon name & $\begin{array}{l}\text { Red List } \\
\text { Category }\end{array}$ & $\begin{array}{l}\text { Red List } \\
\text { Criteria }\end{array}$ & Geographic Distribution \\
\hline D. affinis & $\mathrm{LC}$ & & Brazil, French Guiana, Guyana, Venezuela \\
\hline D. attenuistylus & $\mathrm{EN}$ & B2ab(ii,iii,iv) & Brazil, French Guiana, Suriname, Venezuela \\
\hline D. brownsbergensis & EN & B2ab(ii,iii,iv) & Brazil, Guyana, Suriname \\
\hline D. cissifolia & $\mathrm{LC}$ & & $\begin{array}{l}\text { Belize, Bolivia, Brazil, Colombia, Costa Rica, Ecuador, Guatemala, } \\
\text { Guyana, Honduras, Mexico, Nicaragua, Panama, Peru, Venezuela }\end{array}$ \\
\hline D. fragrans & $\mathrm{EN}$ & B2ab(ii,iv) & Brazil, French Guiana, Suriname \\
\hline D. gentryi & NT & & Brazil, Peru \\
\hline D. hastata & $\mathrm{EN}$ & B2ab(ii,iv) & Brazil \\
\hline D. megacarpa & $\mathrm{EN}$ & B2ab(i,ii,iv) & Brazil, Venezuela \\
\hline D. micrantha & LC & & Brazil, French Guiana, Peru, Suriname, Venezuela \\
\hline D. olympiana & EN & B2ab(i,ii,iii,iv) & Brazil, Guyana \\
\hline D. parvibracteata & $\mathrm{LC}$ & & Brazil, Guyana, eastern Venezuela, Suriname \\
\hline D. pernambucensis & $\mathrm{LC}$ & & Brazil \\
\hline D. scandens & $\mathrm{LC}$ & & $\begin{array}{c}\text { Caribbean Islands (Cuba, Dominican Republic, Dominica, Haiti and } \\
\text { Puerto Rico), North America (United States, Mexico), Central (Belize, } \\
\text { Costa Rica, El Salvador, Guatemala, Nicaragua), South (Argentina, } \\
\text { Bolivia, Brazil, Colombia, French Guiana, Guyana, Paraguay, Peru), } \\
\text { Africa (South Africa, Burkina Faso, Cabo Verde, Eswatini, Ethiopia, } \\
\text { Kenya, Madagascar, Mayotte, Tanzania), Asia (India, Omã, United Arav } \\
\text { Emiratos, Yemen) }\end{array}$ \\
\hline D. triphylla & $\mathrm{LC}$ & & Brazil, Guyana, Paraguay, Suriname \\
\hline
\end{tabular}




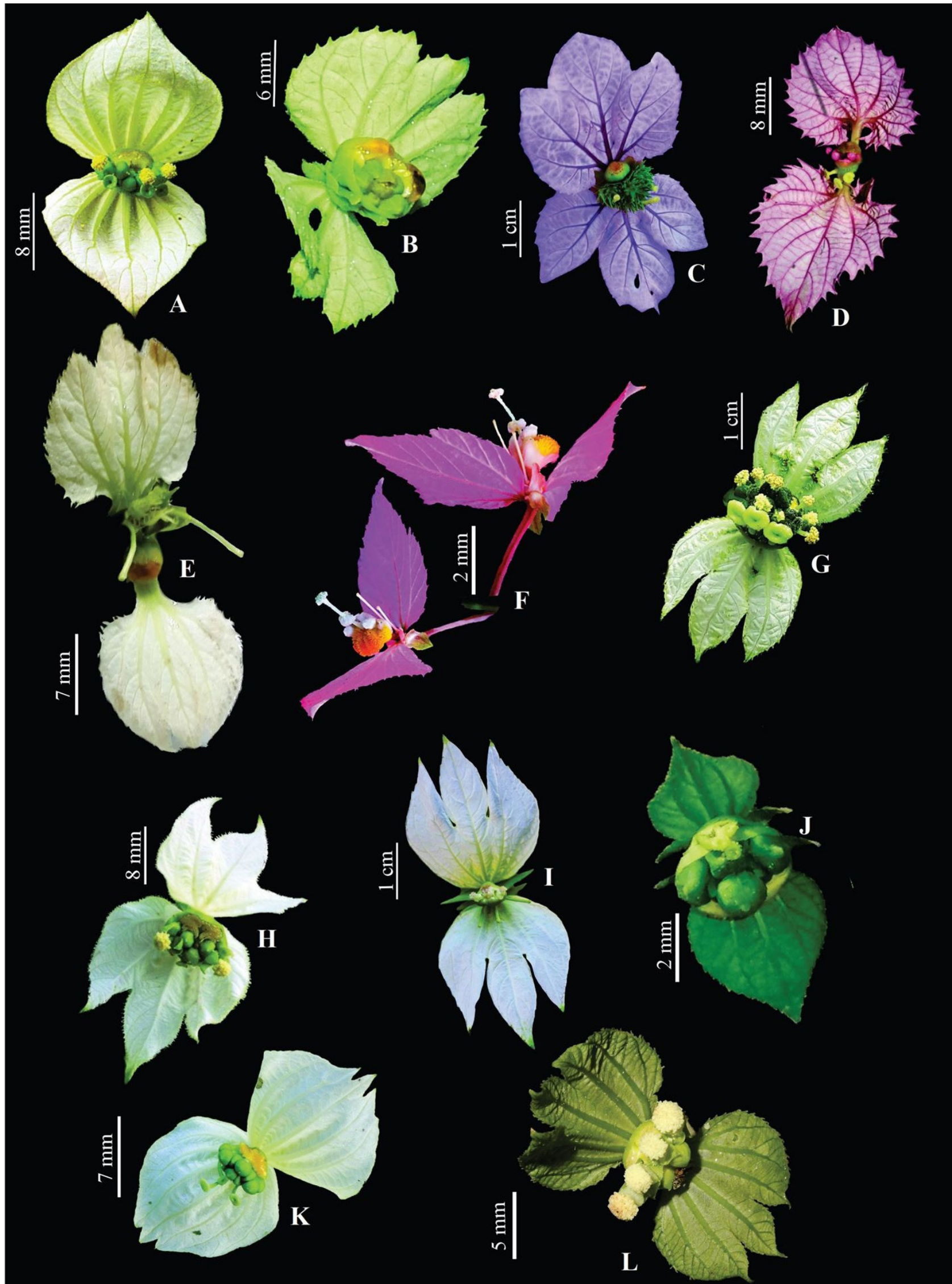

Figure 3 - A-L. Pseudanthium of some Dalechampia species found in the Brazilian Amazon: A. D. affinis; B. D. cissifolia; C. D. cujabensis; D. D. dioscoreifolia; E. D. juruana; F. D. magnoliifolia; G. D. pernambucensis; H. D. scandens; I. D. sylvestris; J. D. tenuiramea; K. D. tiliifolia; L. D. tryphylla.(Photo: B-J - Marcos Silveira, L - Josimar Kulkamp). 
MENDES, J.C.R. et al.

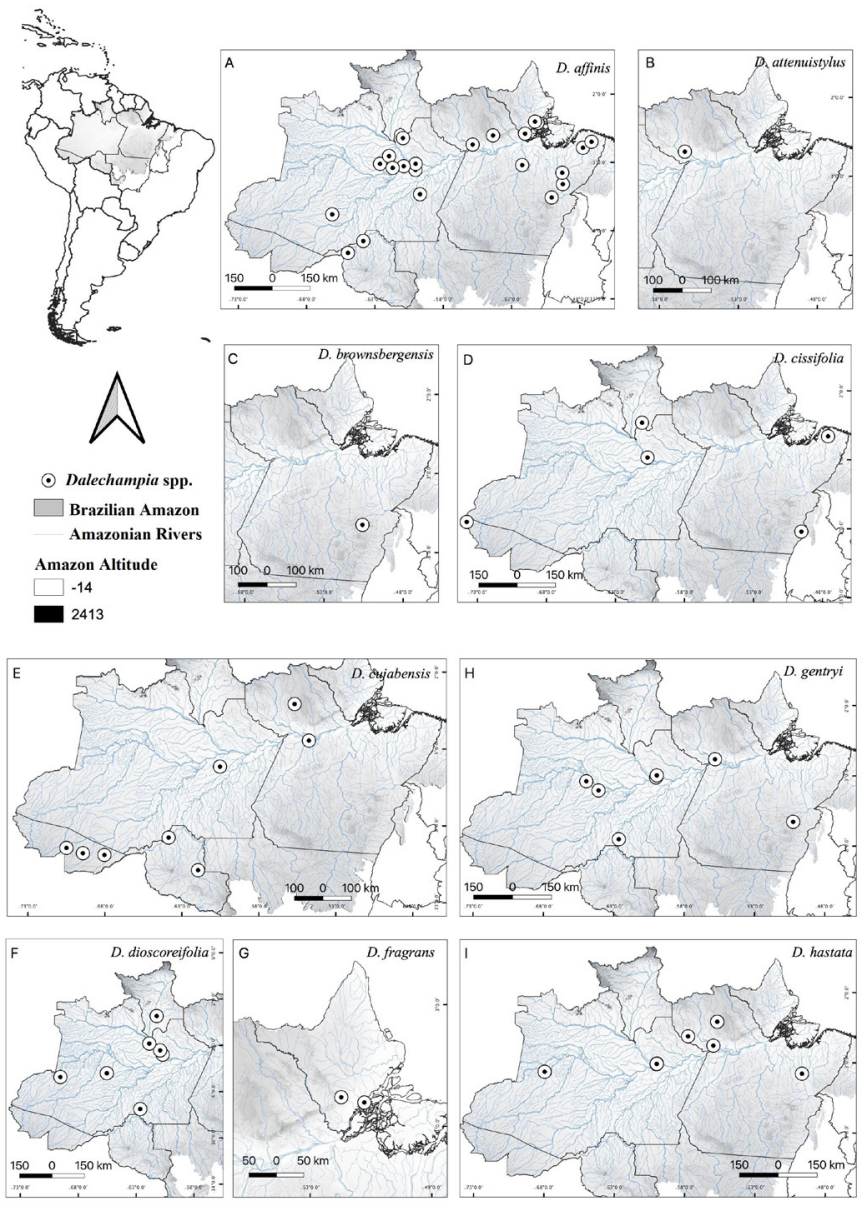

Figure 4 - Geographic distribution of Dalechampia species found in Brazilian Amazon. A. Dalechampia affinis, B. D. attenuistylus, C. D. brownsbergensis, D. D. cissifolia, E. D. cujabensis, F. D. dioscoreifolia, G. D. fragrans, H. D. gentry and I. D. hastata.

Dalechampia attenuistylus Armbr., Brittonia 41(1): 44. 1989. Type: VENEZUELA. Bolivar: Santa Elena de Uairen, W.S. Armbruster et al. 87-153 (holotype MO3891229!; isotype NY00263017!).

Figure 2E-H

Twining vine. Leaves simple, petiolar stipule $3-8 \mathrm{~mm}$ long, in pairs, deciduous, lanceolate to ovate; petiole 1-5 cm long, strigose; leaf blade, unlobed, 3-9.5 × 2.5-7 cm, ovate, base slightly cordate, usually narrow, $\mathrm{V}$-shaped at petiole base, apex cuspidate, margin entire to slightly undulate, adaxial surface sparsely strigose, abaxial surface densely strigose; chartaceous; venation campylodromous; primary veins $5(-7)$; stipels 2, 1-2 mm long, lanceolate, persistent. Pseudanthium terminal, 1 to 2 axillary axes, peduncle $3.5-8 \mathrm{~cm}$ long; involucral bracts $3-10 \times$ $0.5-3 \mathrm{~mm}$, green, stipuliform, lanceolate, sparsely strigose on adaxial and abaxial surfaces, apex acuminate, base cuneate, margin entire, primary veins $3(-5)$, bracteal stipules $2,2-3 \mathrm{~mm}$ long, lanceolatefalcate. Staminate pleiochasium 10-11-flowered, peduncle $3.5-7 \mathrm{~mm}$ long, densely pubescent; staminate bracteoles 4, 0.5-1.5 × 1.5-2.5 mm, broadly ovate, free, adaxial surface pubescent, abaxial surface glabrous; resiniferous glands not present. Staminate flowers, articulated pedicel ca. $0.7 \mathrm{~mm}$ long; pedicel 1-3.5 mm long; sepals $4(-5), 3.5-4 \times 0.5-1$ $\mathrm{mm}$, obovate-oblong; stamens $8-10$, staminal tube $2-2.5 \mathrm{~mm}$ long; anthers bithecate, rimose. Pistillate cymule 3-flowered, sessile; pistillate bracteoles 3, 1.5-4 × 0.5-3 mm, deltoid to obovate, free, adaxial surface glabrous, abaxial surface pubescent, margin entire-ciliate. Pistillate flowers, pedicel 2-3.5 mm long, sepals 6, 2.5-4 × 0.5-1 mm, entire, lanceolate, margin ciliate; ovary 1.5-2 $\mathrm{mm}$ diam, tomentose; stylar column 7-9 mm long, apex subcylindrical (tapering at base, with stigma tip $1 / 3$ enlarged-lanceolate). Capsule $7-8 \mathrm{~mm}$ diam, grayish, strigose, pedicel in fruit 12-23 mm long, pistillate sepals persistent. Seed ca. 4 mm diam., globose, smooth, whitish with dark brown macules.

Distribution, habitat, and conservation status: northern Brazil, French Guiana, southern Suriname, and southeastern Venezuela [Bolivar] (Webster \& Armbruster 1991; Armbruster 1996, 1999; Mendes et al. 2019). In Brazil, it is restricted to the North Region (Pará; Figura 4B) (Mendes et al. 2019). In the study area, this species is found in open forest and the lower canopy of wet riparian forest, near sea level to $40 \mathrm{~m}$. According to IUCN (2019) criteria, the species is designated as Endangered (EN) under sub-criteria B2ab(ii,iii, iv), due to its $\mathrm{AOO}$ of $20.000 \mathrm{~km}^{2}$ and found in only four locations (see Table 1). It is threatened because it is found in places where there is an anthropic pressure, especially from the extraction of gold mining and deforestation (Serra dos Carajás/PA).

Phenology: Flowers and fruits in mid-late December (Armbruster 1996).

Taxonomic Notes: Dalechampia attenuistylus is distinct from the other studied species due to the shape of the subcylindrical stylar column, apex $1 / 3$ enlarged-lanceolate, and stipuliform involucral bracts. The species is morphologically similar to D. megacarpa because it has the same fruit type. However, D. attenuistylus differs by having capsules 7-8 $\mathrm{mm}$ diam (vs. 5-5.5 cm diam in D. megacarpa) and larger seeds, ca. $4 \mathrm{~mm}$ diam (vs. 9-11 $\mathrm{mm}$ diam).

Examined Material: BRAZIL. PARÁ: Oriximiná, Porto Trombetas, 1'28'S, 56²2'W, 1994, fl., fr., Evandro \& Knowles 1286 (INPA).

Dalechampia brownsbergensis G.L. Webster \& Armbr., Syst. Bot. 7(4): 484. 1982. Type: SURINAME. Distr. Brokopondo: Brownsberg, G.L. Webster and W.S. Armbruster 24124 (holotype DAV95970!; isotypes NY00263018!, TEX00371648!, U0001902!).

Figure 2I-L

Twining vine. Leaves simple, petiolar stipule 4.5-10 $\mathrm{mm}$ long, in pairs, persistent, elliptic-lanceolate; petiole $4.5-10 \mathrm{~cm}$ long, pubescent; leaf blade, 3-lobed, lobes 10-20 × 10-25 cm, base deeply cordate, apex 3-lobed, margin entire, minutely glandular when young, adaxial surface copiously pubescent, abaxial surface glabrous; chartaceous, venation campylodromous; primary veins 7; stipels $2(-4), 1.5-2.5 \mathrm{~mm}$ long, lanceolate, persistent. Pseudanthium axillary, peduncle $1.5-4.5 \mathrm{~cm}$ long; involucral bracts $2.5-4 \times 2.5-4.5 \mathrm{~cm}$, pale green, broadly ovate, adaxial and abaxial surfaces velutinous, apex 3 -toothed, base cordate, margin entire (minutely and obscurely glandular-denticulate), primary veins 9 (-11); bracteal stipules 4, 4-6 mm long, lanceolate. Staminate pleiochasium 12-19-flowered; peduncle 1.5-2.5 mm long, hirsute; staminate bracteoles $2,2-3 \times 6.5-8 \mathrm{~mm}$, wide-punctate, connate, adaxial and abaxial surfaces glabrous; resiniferous glands 5.5-6 $\times 0.5-1 \mathrm{~mm}$, punctiform, inconspicuous, vestigial, secreted resin absent. Staminate flowers, articulated pedicel, robust $0.5-3 \mathrm{~mm}$ long.; pedicel $1.5-3$ mm long; sepals 3-5, 2.5-3 × 1-1.5 mm, lanceolate; stamens 12-15, staminal tube 3-4 mm long; anthers bithecate, rimose. Pistillate cymule 3-flowered, sessile peduncle; pistillate bracteoles 3, 2.5-4 × 6.5-8.5 
$\mathrm{mm}$, reniform, connate, adaxial, and abaxial surfaces pubescent, margin slightly ciliate. Pistillate flowers, pedicel 1-1.5 mm long; sepals 10-12, ca. $1.5 \times 0.5-0.9 \mathrm{~mm}$, pinnatisect-laciniate, stipitate-glandular trichomes on the lobes; ovary 1.5-2 mm diam, hispidulous; stylar column 7-9 $\mathrm{mm}$ long, linear, apex trigonous. Capsule $7.5-8 \mathrm{~mm}$ diam, brownish, glabrous, with persistent pistillate sepals and stylar column. Seed ca. $3.5 \mathrm{~mm}$ diam, globose, smooth, whitish with dark brown macules.

Distribution, habitat and conservation status: Brazil, Guyana [new occurrence], and Suriname (Webster \& Armbruster 1982, 1991; Armbruster 1999). In Brazil, it occurs in the North (Pará; Figure 4C) and Northeast (Pernambuco) regions, with a disjunct distribution between the two Brazilian states and populations found in isolation (Mendes et al. 2019). In the study area, the species was found in the rainforest canopy, near sea level to $235 \mathrm{~m}$. According to IUCN (2019) criteria, the species is designated as Endangered (EN) under sub-criteria B2ab(ii,iv,iv), due to its AOO of $24.000 \mathrm{~km}^{2}$ occurring in six locations (see Table 1). Since human pressures, such as the extraction of ore (Serra de Carajás, PA) and monoculture of exotic specie (Musa sp.) in Brejos Nordestinos (PE), threaten this species of extinction, since its subpopulations are probably very small.

Phenology: Flowers and fruits from February to December (Brazilian Amazon).

Taxonomic Notes: Dalechampia brownsbergensis is superficially similar to D. tiliifolia due to the shape of the leaves and pseudanthium. However, they differ by the following: leaf blade exclusively 3-lobed (vs. unlobed, with a lateral lobe to 3-lobed on the same individual in $D$. tiliifolia) with a deeply cordate ( $v s$. cordate) base; and involucral bracts widely ovate, apex 3-toothed, pale green at anthesis ( $v s$. ovate, lightly 3-dentate, creamy white). The most striking difference is the nature of the resiniferous gland complex, which is reduced in D. brownsbergensis, with scattered glands by the abaxial side of the staminate pleiochasium that are dark, punctate, and not resiniferous (vs. aggregated, yellowish, fimbriate, resiniferous glands in D. tiliifolia).

Examined Material: BRAZIL. PARÁ: Parauapebas, Serra de Carajás, $6^{\circ} 18^{\prime}$ S, 5036'W, 5.XII.2017, fl., fr., F.A. Silva et al. 281 (INPA, MG, RB).

Dalechampia cissifolia Poepp., Nov. Gen. Sp. Pl. 3: 20. 1841. Type: PERU. Maynas: Yurimaguas, E.F. Poeppig 2085 (lectotype W0023463!, designated by Armbruster and Webster 168: 1991; isolectotypes G00236456!, LE00006855!).

Figure 2M-Q; Figure 3B

Twining vine. Leaves compound, petiolar stipule 4-8 $\mathrm{mm}$ long, in pairs, persistent, lanceolate; petiole 4-7 cm long, hispid-pubescent; leaf blade, 3-foliolate; middle leaflet 5.5-10.5 × 3.5-5 cm, obovate to obovate-oblong, base acute, apex attenuate to acuminate; lateral leaflets 4-9.5 × 3-5 cm, oblique-ovate, apex acute; margin denticulate, adaxial surface slightly pubescent, abaxial surface sparsely pubescent to glabrous; chartaceous; venation eucamptodromous; primary veins 5; stipels 2, 2-3 mm long, triangular, persistent or rarely deciduous. Pseudanthium axillary, peduncle $1-3 \mathrm{~cm}$ long; involucral bracts $1-1.6 \times$ $0.8-1.6 \mathrm{~cm}$, greenish, orbicular-ovate, adaxial surface hirsutous, abaxial surface pubescent, apex slightly 3-lobed, base round to lightly cordate, margin denticulate, primary veins 5 ; bracteal stipules $2,3.5-5 \mathrm{~mm}$ long, triangular-lanceolate. Staminate pleiochasium 8-9-flowered, peduncle ca. $1 \mathrm{~mm}$ long, sparsely pubescent; staminate bracteoles $2,1.5-2 \times$
5-8 $\mathrm{mm}$, reniform, connate, adaxial and abaxial surfaces glabrous; resiniferous glands $1.5-2 \times 2-2.5 \mathrm{~mm}$, laminar. Staminate flowers, articulated pedicel 3-4 mm long; pedicel 2-3 mm long, sepals 4-5, $1.5-2 \times 0.5-1 \mathrm{~mm}$, lanceolate; stamens $23-26$, staminal tube ca. $1 \mathrm{~mm}$ long; anthers bithecate, rimose. Pistillate cymule 3 -flowered, peduncle subsessile, pubescent; pistillate bracteoles $3,1.5-2 \times 2-3 \mathrm{~mm}$, reniformovate, connate, adaxial surface strigose, abaxial surface glabrous, margin ciliate-glandular. Pistillate flowers, pedicel 1-1.2 mm long; sepals 8-12, $3-4 \times 0.5-0.8 \mathrm{~mm}$, linear-lanceolate, pinnatifid, margin with stipitateglandular trichomes; ovary 1-1.5 mm diam, pubescent; stylar column 1.5-5 mm long, linear, apex obovate. Capsule $8 \mathrm{~mm}$ diam, light brown, slightly strigose, with small persistent pistillate sepals and stylar column. Seeds $3 \mathrm{~mm}$ diam, ovoid, smooth, light brown with dark brown macules.

Distribution, habitat, and conservation status: Belize [new occurrence], Bolivia, Brazil, Colombia [new occurrence], Costa Rica, Ecuador, Guatemala [new occurrence], Guyana, Honduras [new occurrence], Mexico, Nicaragua [new occurrence], Panama, Peru, and Venezuela (Webster \& Armbruster 1991; Gillespie \& Armbruster 1997). In Brazil, it occurs in the North Region (Acre, Amazonas, Pará, Roraima; Figure 4D) (Pereira-Silva et al. 2020a). In the study area, it is found in the canopy on banks in rainforest, near sea level to $735 \mathrm{~m}$. According to IUCN (2019) criteria, the species is designated as Least Concern (LC), due to its EOO of 11,198,406.981 km² (see Table 1). Although, if we consider the occurrence only in Brazil, the taxon can be designated as Vulnerable (VU) under criteria subcriteria B2ab(i,ii, iii, iv) because some populations are in place with high human pressure.

Phenology: Flowers and fruits from February to September (Brazilian Amazon).

Taxonomic Notes: Dalechampia cissifolia has affinity to $D$. triphylla, although they can be easily differentiated by the following, middle obovate to obovate-oblong leaflet ( $v$ s. lanceolate in D. triphylla); involucral bracts orbicular-ovate ( $v s$. ovate), base rounded to slightly cordate ( $v s$. truncate to subcordate), apex slightly 3-lobed ( $v s$. deeply 3-lobed/acuminate); and pistillate sepals pinnatisect, linear-lanceolate (vs. widely pinnatifid, triangular-ovate).

Nomenclatural notes: Dalechampia cissifolia was described by Eduard Poeppig (1841) based on the specimens collected in "crescit in fruticetis ad Yurimaguas, prov. Maynas". Webster \& Armbruster (1991) indicated that the holotype would be at W. However, E. Poeppig did not specify a specimen and the herbarium where it was deposited., so when Webster \& Armbruster mention holotype, they did an inadvertent lectotypification, according to Art. 7.11 (Ex. 13) and Art. 9.10 (Ex. 11) of the ICN (Turland et al. 2018). In addition, we found one specimen at LE that is D. cissifolia isolectotype.

Examined Material: BRAZIL. ACRE: Serra do Moa, 7³0'S, 734' 'W, 24.IV.1971, fl., fr., G.T. Prance et al. 12380 (INPA, MG, MO, NY). AMAZONAS: Manaus, 306'S, 6001'W, 14.III.3.1977, fl., A.H. Gentry et al. 18279 (INPA, MO). PARÁ: Colônia do Prata, $1^{\circ} 25^{\prime}$ 'S, 48²6'W, 24.IX.1903, fl., J. Huber (MG3820); Conceição do Araguaia, $8^{\circ} 25^{\prime}$ S, $49^{\circ} 26^{\prime} \mathrm{W}$, VII.1983, fl., fr., C.H. Tokarnia 1434 (INPA). RORAIMA: Near Maitá Indian village, $3^{\circ} 20^{\prime} \mathrm{S}, 63^{\circ} 24^{\prime} \mathrm{W}$, 14.II.1971, fr., G.T. Prance et al. 10523 (INPA, NY, US); Caracaraí, 1³8'S, 6156'W, 25.VII.2010, fl., G.C. Delgado-Junior \& S.C. Belo 121 (INPA). 
MENDES, J.C.R. et al.

Dalechampia cujabensis Müll. Arg., Linnaea 34: 222. 1865. Type: BRAZIL. MATO GROSSO: Cuiabá, February 1829, A.L.P. da Silva Manso 53 in Hb. Fl. Bras., C.F.P. von Martius 845 (lectotype G00209171!, designated by Mendes et al. 190: 2019; isolectotypes BR0000005101184!, BR0000005109661!, BR0000005109999!, HALL0118564!, M0233658!, NY00263020!, P00640211!).

Figure 5A-F; Figure 3C

Twining vine. Leaves simple, petiolar stipules 3-7 3 4-5 mm, in pairs, deciduous, ovate; petiole $3.5-12.5 \mathrm{~cm}$ long, strigose; leaf blade, 3-lobed, lobes 8-16 × 15-25 cm, base deeply cordate, apex cuspidate, margin slightly denticulate, subcoriaceous, adaxial surface glabrous, abaxial surface sparsely strigose; venation campylodromous; primary veins 5; stipels 2, 2-4 mm long, narrowly triangular, persistent. Pseudanthium axillary, peduncle 5-7 cm long; involucral bracts 3-4.5 $\times 4.5-5 \mathrm{~cm}$, purplish, with veins purplish and prominent, broad-elliptic, adaxial and abaxial surfaces strigose, apex 3-lobed, base decurrent to rounded, margin denticulate, primary veins 5 ; bracteal stipule 4 , 8-12 mm long, widely ovate. Staminate pleiochasium 8-10-flowered; peduncle ca. $1.5 \mathrm{~mm}$ long, hirsute; staminate bracteoles $4,2-3 \times$ 1.5-2 mm, suborbicular, free, adaxial surface glabrous, abaxial surface pubescent; resiniferous glands $3.5-4 \times 4.5-5 \mathrm{~mm}$, laminar. Staminate flowers, articulated pedicel ca. $2 \mathrm{~mm}$ long; pedicel $0.5-1 \mathrm{~mm}$ long; sepals 6-10, 5-6 × 2-2.5 mm, lanceolate; stamens 80-90, staminal tube

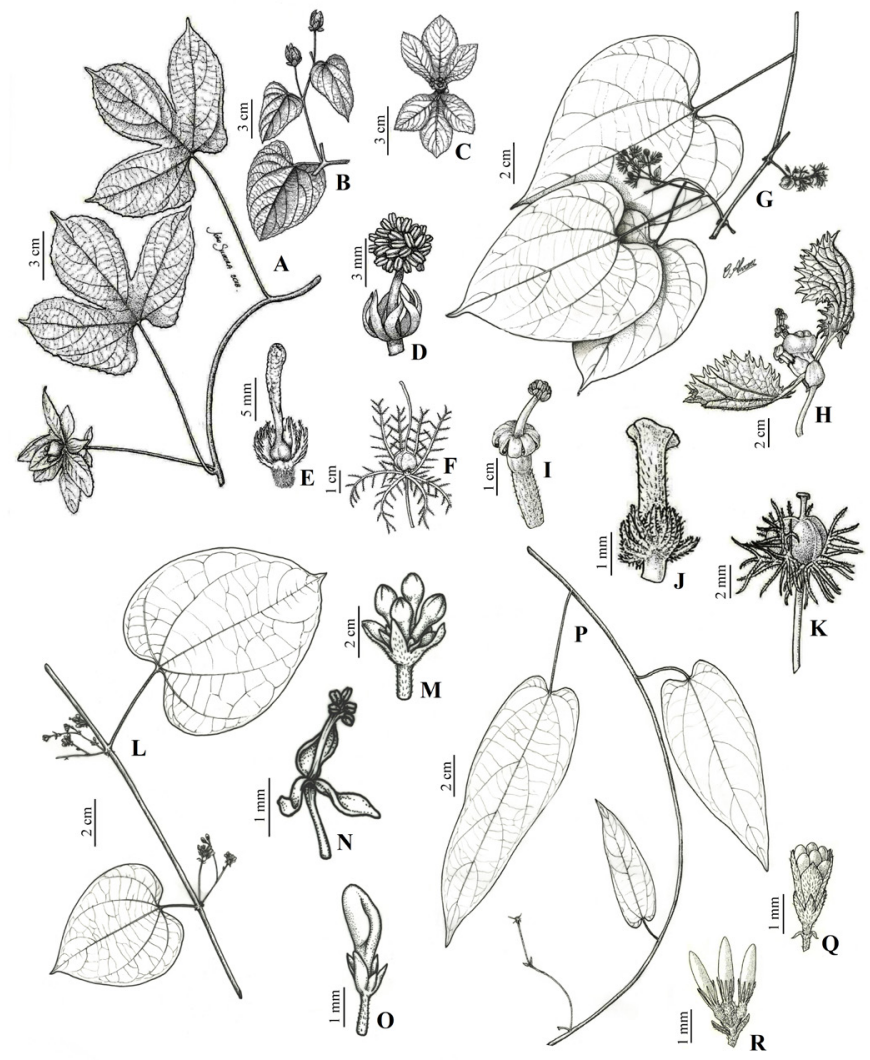

Figure 5 - A-F. Dalechampia cujabensis - A, B. branch; C. pseudanthium; D. staminate flower; E. pistillate flower; F. fruit showing pistillate sepals (Bigio, N.C. 209). G-K. D. dioscoreifolia - G. branch; H. pseudanthium; I. staminate flower; J. pistillate flower; K. fruit (Prance, G.T. et al. 11053). L-O. D. fragrans - L. branch; M. staminate pleiochasium; N. staminate flower; O. pistillate flower (Pires, M.J. \& Silva, N.T. 1396). P-R. D. gentryi-P. branch; Q. pistillate cymule; R. staminate pleiochasium (Silva, M. 1724). ca. $3 \mathrm{~mm}$ long; anthers bithecate, rimose. Pistillate cymule 3 -flowered, peduncle ca. $2 \mathrm{~mm}$ long, pubescent; pistillate bracteoles $3,0.8-1 \times$ $0.6-1 \mathrm{~mm}$, oval to elliptical, free, adaxial surface strigose, abaxial surface glabrous, margin ciliate. Pistillate flowers, pedicel ca. $0.7 \mathrm{~mm}$ long; sepals 10-12, 0.4-0.8 mm long, pinnatifid-ciliate, hirsute, without stipitate-glandular trichomes; ovary ca. $2 \mathrm{~mm}$ diam, glabrous to slightly strigose; stylar column ca. $9 \mathrm{~mm}$ long, linear, apex papillose (verrucose). Capsule 1-3 mm diam, brown, slightly strigose, with tightly persistent sepals and stylar column. Seed $5 \mathrm{~mm}$ diam, ellipsoid, smooth, light brown with brown macules.

Distribution, habitat and conservation status: Bolivia, Brazil, and Peru (Webster \& Armbruster 1991). In Brazil, it occurs in the CentralWest (Mato Grosso) and North (Acre, Amazonas, Pará, Rondônia; Figure 4E) regions (Webster \& Armbruster 1991; Mendes et al. 2019). In the study area, it is usually found in terra firme (primary and secondary) and lowland (flood plain) forests, near sea level to $299 \mathrm{~m}$. According to IUCN (2019) criteria, the species is designated as Least Concern (LC), due to its EOO of 3,093,550.120 $\mathrm{km}^{2}$ (see Table 1).

Phenology: Flowers and fruits from February to September (Brazilian Amazon).

Taxonomic Notes: Dalechampia cujabensis is easily recognized by the following: leaf blade sucoriaceous $(8-16 \times 15-25 \mathrm{~cm})$, deeply 3-lobed, petiolar stipule showy $(3-7 \times 4-5 \mathrm{~mm})$, ovate; involucral bracts cream to purplish, with purplish prominent veins, bracteal stipule 4, (8-12 mm long) widely ovate; and fruits green with persistent, fimbriate and showy pistillate sepals. We emphasize that the specimens collected in the domain of the Brazilian Amazon, differ only by the leaf morphology of those found in the Brazilian Cerrado (see Mendes et al. 2019), thus configuring these two biomes as probable ecotypes of D. cujabensis with a disjunct distribution quite remarkable, associated with the environment.

Selected Material: BRAZIL. ACRE: Santa Rosa do Purus, 9²6'S, 7052'W, 26.III.1999, fl., D.C. Daly et al. 10104 (NY, UFACPZ); Sena Madureira, 9¹9'S, 68¹9'W, 9.III.2013, fl., D.S. Costa et al. 81 (RB). AMAZONAS: Rio Acre, 6² $41^{\prime}$ S, 6303'S, II.1911, fl., fr., E. Ule 9541 (MG). PARÁ: Óbidos, $1^{\circ} 41^{\prime} \mathrm{S}, 55^{\circ} 34^{\prime} \mathrm{W}, 17 . \mathrm{III} .1915$, fr., A. Ducke (MG15729, RB187659); Santárém, $2^{\circ} 13$ 'S, 54²42'W, 14.IX.1969, fr., $M$. Silva \& R. Souza 2248 (MG, NY). RONDÔNIA: Porto Velho, 1051'S, 65¹6'W, 25.IV.2010, fl., fr., N.C. Bigio 206 (RON, MG).

Dalechampia dioscoreifolia Poepp., Nova Gen. Sp. P1. 3: 20. 1841. Type: PERU. Maynas, E.F. Poeppig 2163 (lectotype W0023459!, designated by Webster and Armbruster 155: 1991).

Figure 5G-K; Figure 3D

Twining vine. Leaves simple, petiolar stipules $4-5 \times 0.8-1 \mathrm{~mm}$, in pairs, persistent, linear-lanceolate; petiole $1.5-6.5 \mathrm{~cm}$ long, hirsutous; leaf blade, unlobed, $6.5-12.5 \times 4.5-8 \mathrm{~cm}$, ovate, base deeply cordate, apex acuminate, margin denticulate-glandular, adaxial surface hirsutous, abaxial surface strigose; chartaceous, venation campylodromous; primary veins $4(-5)$; stipels $2,1.5-2 \mathrm{~mm}$ long, ensiform, persistent. Pseudanthium axillary, peduncle $4-8 \mathrm{~cm}$ long; involucral bracts $3-5 \times$ $2-4.5 \mathrm{~cm}$, pale pinkish, with vinaceous veins, triangular to rhomboidovate, adaxial surface strigose on the veins, abaxial surface glabrous, apex acute, base unguiculate, margin incise-dentate, primary veins $5(-7)$, bracteal stipule $4,0.8-1 \mathrm{~mm}$ long, ovate to lanceolate-ovate. Staminate pleiochasium 8-10-flowered, peduncle 2-2.5 $\mathrm{mm}$ long, 
sparsely pubescent; staminate bracteoles 4, 4-5 × 5-7 mm, subround, free, adaxial surface glabrous, abaxial surface densely strigose; resiniferous glands 3-4×2-3 mm, subcylindrical, with brownish-brown resin. Staminate flowers, articulated pedicel $2-3 \mathrm{~mm}$ long; pedicel $2.5-3$ mm long; sepals 7, 2.5-3.5 ×0.8-1 mm, linear-lanceolate; stamens 8-15, staminal tube ca. $3 \mathrm{~mm}$ long; anthers bithecate, rimose. Pistillate cymule 3-flowered, peduncle 1-2 mm long, pubescent; pistillate bracteoles 3 , 4-4.5 $\times 2.5-4 \mathrm{~mm}$, cucullate-orbicular, free, adaxial and abaxial surfaces glabrous, margin ciliate. Pistillate flowers, pedicel 1-3 mm long; sepals 6-12, 6-10 × 1-5 mm, pinnatisect-lacinulate, without stipitate-glandular trichomes; ovary $2-2.5 \mathrm{~mm}$ diam, densely strigose to sericeous; stylar column 3.5-4 mm long, linear, apex piliform-dilated. Capsule ca. $5 \mathrm{~cm}$ diam, brown, glabrous, pedicel fructiferous, $2 \mathrm{~cm}$ long, sepals tightly persistent. Seed $5 \mathrm{~mm}$ diam, subspherical, rugose, brown with lightbrown macules.

Distribution, habitat and conservation status: Brazil, Colombia, Costa Rica, Ecuador, French Guiana, Mexico [new occurrence], Nicaragua, Panama, Peru, and Venezuela (Gillespie \& Armbruster 1997; Armbruster 1999; Webster \& Armbruster 1991). In Brazil, it occurs in the Central-West (Mato Grosso, Mato Grosso do Sul) and North (Amazonas, Roraima; Figure 4F) regions (Pereira-Silva et al. 2020a). In the study area, the species is usually found on forest edges or in primary or secondary rainforest, near sea level to $1,069 \mathrm{~m}$. According to IUCN (2019) criteria, the species is designated as Least Concern (LC), due to its EOO 5,753,408.349 $\mathrm{km}^{2}$ (see Table 1). Although, if we consider the occurrence only in Brazil, known for only two localities, the taxon can be designated as Vulnerable (VU) under criteria subcriteria B2ab(i,ii, iii, iv) because some populations are in place with high human pressure.

Phenology: Flowers and fruits from February to December (Brazilian Amazon).

Taxonomic Notes: When vegetative, D. dioscoreifolia is similar to $D$. heterobractea and D. parvibracteata due to the unlobed leaves with a deep, cordate base. However, D. dioscoreifolia can be distinguished from both species by the following: pseudanthium morphology with involucral bracts that are 3-5 $\times 2-4.5 \mathrm{~cm}$, pale pinkish and triangular to rhomboid-ovate, with vinaceous veins, unguiculate base, and incise-dentate margins; resiniferous gland subcylindric, with brownish resin; pistillate sepals 6-12, pinnatifid-laciniate; stylar column apex piliform-dilated; and fruit $3-4 \mathrm{~cm}$ diam., with persistent, laciniate, pistillate sepals.

Selected Material: BRAZIL. AMAZONAS: Tefé, $3^{\circ} 22^{\prime}$ S, $64^{\circ} 43^{\prime} \mathrm{W}$, 9.VII.1972, fl., fr., PLK \& Urbano 12142 (INPA); São Paulo de Olivença, 3²7'S, 6847'W, 26.IV.1944, fr., L. Fróes 20811 (IAN, NY). RORAIMA: Near Maitá Indian Village, 3²0'S, 63²4'W, 14.II.1971, fl., fr., G.T. Prance et al. 10519 (INPA, NY).

Dalechampia fragrans Armbr., Bot. J. Linn. Soc. 105: 150. 1991. Type: SURINAME. Brownsberg: Nature Park, c. km 13 Plateau Weg, 8 XI 1985, W.S. Armbruster \& A.L. Herzig 85-101 (holotype MO3891230!; isotype NY00263021!).

Figure 5L-O

Twining vine. Leaves simple, petiolar stipules $2.5-4 \mathrm{~mm}$ long, in pairs, deciduous, ovate; petiole $5-18 \mathrm{~cm}$ long, hispid; leaf blade, unlobed, $5.5-22 \times 5-18 \mathrm{~cm}$, ovate, base truncate to cordate, apex acuminate, margin entire to roughly dentate, adaxial and abaxial surfaces glabrous; chartaceous to coriaceous, venation campylodromous; primary veins 5 ; stipels $2,0.5-1 \mathrm{~mm}$ long, lanceolate-falcate, persistent. Pseudanthium axillary, peduncle 3.5-4 mm long; involucral bracts 2-5 $\times 1-3 \mathrm{~mm}$, stipuliform, green at anthesis, discreetly sericeous on the adaxial and abaxial surfaces, apex acute, base cordate, margin entire, primary veins $1(-3)$; bracteal stipule $4(-5), 1.5-2 \mathrm{~mm}$ long, lanceolate. Staminate pleiochasium 12(-13)-flowered, peduncle 1.5-3 $\mathrm{mm}$ long, glabrous; staminate bracteoles 4, 3-3.5 × 1.5-2 mm, lanceolate-ovate, free, adaxial and abaxial surfaces glabrous; resiniferous glands absent. Staminate flowers, articulated pedicel ca. $1.5 \mathrm{~mm}$ long; pedicel 2-4 mm long; sepals 4, 1-1.5 × ca. $0.5 \mathrm{~mm}$, lanceolate; stamens 4-5, staminal tube $2-5 \mathrm{~mm}$ long, anthers bithecate, rimose. Pistillate cymule 3-flowered, subsessile; pistillate bracteoles 3, 3-7 $\times 0.5-3 \mathrm{~mm}$, lanceolate-ovate, free, adaxial and abaxial surfaces glabrous, margin entire. Pistillate flowers, pedicel 2-3 mm long; sepals 6, 3-4 × 0.5-1 $\mathrm{mm}$, entire, lanceolate-ovate, stipitate-glandular trichomes absent; ovary 1.5-2 mm diam, hispid; stylar column 7-10 mm long, obovate, apex ovoid. Fruit and seed not seen.

Distribution, habitat, and conservation status: Brazil, French Guiana and Suriname (Webster \& Armbruster 1991; Armbruster 1996; Gillespie \& Armbruster 1997). In Brazil, it occurs in the North (Amapá; Figure 4G) (Armbruster 1996; Pereira-Silva et al. 2020a). In the study area, the species is found in tropical rainforest, especially in the canopy of trees, near sea level to $10 \mathrm{~m}$. According to IUCN (2019) criteria, the species is designated as Endangered (EN) under sub-criteria B2ab(ii,iv), due to its AOO of $24.000 \mathrm{~km}^{2}$ and found in only six locations (see Table 1). It's endangered, because there are probably few mature individuals. However, a subpopulation of the species is found in a protected area (Brownsberg Nature Park is a nature reserve located in Suriname, but not in ex situ collections.

Phenology: Flowers and fruits from December to May (Brazilian Amazon).

Taxonomic Notes: Dalechampia fragrans is superficially similar to D. micrantha, especially due to the shape of the leaves. It can be differentiated by the widely subcordate ( $v s$. subtruncate to rounded in D. micrantha) base and acuminate ( $v$ s. cuspidate-acuminate) apex of the leaf blade, petiolar stipule ovate ( $v s$. triangular-lanceolate), staminate pleiochasium 12(-13)-flowered (vs. 13-flowered), sepals staminate flowers 4 (vs. 3), stylar column obovate ( $v s$. linear-faveolate) and apex ovoid ( $v s$. truncate).

Selected Material: BRAZIL. AMAPÁ: Mazagão, $0^{\circ} 07^{\prime}$ S, $51^{\circ} 17^{\prime} \mathrm{W}$, 1.X.1986, fl., fr., M.J. Pires \& N.T. Silva 1396 (INPA, MO).

Dalechampia gentryi Armbr., Syst. Bot. 21(2): 223-225. 1996. Type: PERU. Loreto: Nauta, Rio Marañón above mouth of Rio Ucayali, 4³0'S, 73³0'W, A. Gentry et al. 29955 (holotype MO2919945!; isotypes CAS002273!, F0042459!).

Figure 5P-R

Twining vine. Leaves simple, petiolar stipules 3-4 mm long, in pairs, rarely persistent, lanceolate; petiole $2-4.5 \mathrm{~cm}$ long, strigose; leaf blade, unlobed, 6-12 × 3-7.5 cm, ovate, base broadly cordate, apex abruptly acuminate, margin entire, adaxial surface discreetly strigose, abaxial surface densely strigose; chartaceous, venation campylodromous; primary veins 3(-5); stipels 2, 1-1.5 mm long, lanceolate-falcate, persistent. Pseudanthium axillary; peduncle $1-4.5 \mathrm{~mm}$ long; involucral bracts, $2-3$ $\times 0.8-1 \mathrm{~mm}$, stipuliform, green, adaxial surface strigose, abaxial surface glabrous, apex acute to acuminate, base obtuse to rounded, margin entire, 
primary veins $1-2(-3)$; bracteal stipule 4 , ca. $3 \mathrm{~mm}$ long, lanceolate. Staminate pleiochasium 8-flowered, peduncle 1-2 mm long, pubescent; staminate bracteoles $4,1-1.5 \times 0.5-0.9 \mathrm{~mm}$, lanceolate, free, adaxial and abaxial surfaces strigose; resiniferous glands absent. Staminate flowers, articulated pedicel 1-1.5 mm long; pedicel $0.8-1 \mathrm{~mm}$ long; sepals 4, ca. 3-4 $\times 2-2.5 \mathrm{~mm}$, lanceolate; stamens 4-6, staminal tube $0.2-0.4 \mathrm{~mm}$ long; anthers bithecate, rimose. Pistillate cymule 3-flowered, peduncle 4-12 mm long, strigose; pistillate bracteoles 3, 3-5 × 0.5-2.5 mm, linear-lanceolate, free, adaxial and abaxial surfaces slightly hirsutous, margin entire. Pistillate flowers, pedicel 1.5-2 mm long; sepals ca. 5 (-6), 4-6 × 0.3-1 $\mathrm{mm}$, entire, linear-lanceolate, hirsutous; ovary $1-1.5 \mathrm{~mm}$ diam, densely hispid; stylar column 8-10 mm long, oblanceolate, apex obtuse. Capsule 6-7 mm diam, light-brown, strigose, pistillate sepals not present. Seed ca. $4.5 \mathrm{~mm}$ diam, subspherical, light brown with dark brown macules.

Distribution, habitat, and conservation status: Brazil and Peru (Armbruster 1996). In Brazil, it occurs in the North (Amazonas, Pará; Figure 4H) region (Armbruster 1996; Pereira-Silva et al. 2020a). In the study area, this species is commonly found in moist secondary dryland forest, close to near sea and river level at $168 \mathrm{~m}$. According to IUCN (2019) criteria, the species is designated as Near Threatened (NT), due to its EOO 1,360,309.359 $\mathrm{km}^{2}$ (see Table 1). However, the species occurs near sea level and rivers in humid secondary forests, and erosion, especially on riverbanks in the Brazilian Amazon, is constant, causing habitat loss. Additionally, the construction of hydroelectric dams also contributes to the alteration of river flow, changing landscapes, thus threatening species adapted and dependent on floodable habitats. These risks are reflected in the dams built by mining companies (e.g., Oriximiná and Parauapebas/PA) that are at high risk of collapse, if it happens, causing the loss of habitat for many species as well, as happened in Brumadinho and Mariana in Minas Gerais. For all these facts and its relatively small extent of occurrence $(\mathrm{EOO})\left(=1,360 \mathrm{~km}^{2}\right)$, D. gentryi is assessed as Near Threatened (NT).

Phenology: Flowers and fruits from February to October (Brazilian Amazon).

Taxonomic Notes: Dalechampia gentryi is morphologically closer to D. hastata since both have linear-lanceolate sepals (an unusual sepal shape in this section). However, the former differs by the following: leaves unlobed, ovate ( $v s$. unlobed, lanceolate and usually with 2-3 lateral lobes in the same individual in D. hastata), base widely cordate ( $v s$. base cordate to hastate), margin entire, without glands ( $v s$. serrulate, glandular); peduncle 4-12 mm long, strigose (vs. 2-3 cm long, hirsutous); stylar column 8-10 mm long, oblanceolate (vs. 4-7 $\mathrm{mm}$ long, obovate), apex obtuse (vs. rounded); and seed subspherical, slightly flattened ( $v s$. subspherical, globose).

Selected Material: BRAZIL. AMAZONAS: Coarí, 405'S, 630' 'W, 13.V.1971, fl., fr., C. Byron et al. 443 (INPA, MO); Reserva Ducke, 253'S, 5958'W, 19.XI.1997, fl., J.E.L.S. Ribeiro et al. 1946 (INPA, MG). PARÁ: Oriximiná, $1^{\circ} 45^{\prime}$ 'S, 5551'W, 24.VIII.1968, fl., fr., M. Silva 1724 (MG); Parauapebas, 604'S, 4954'W, 26.IX.1989, fl., J.P. Silva 576 (MG).

Dalechampia hastata G.L. Webster, Bot. J. Linn. Soc. 105: 151. 1991. Type: BRAZIL. Amazonas: Manaus, km 9 da BR-17, 16 March 1955, W.A. Rodrigues s.n INPA 886 (holotype MG021508!; isotype INPA198301!).

Figure 6A-D

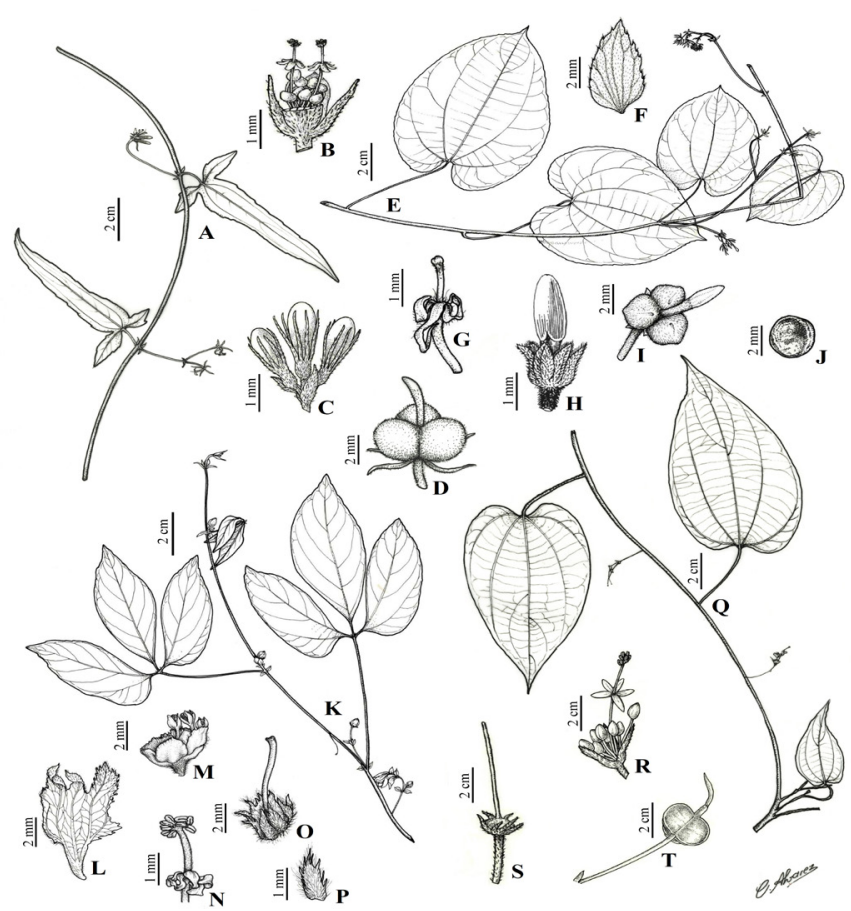

Figure 6. A-D. Dalechampia hastata - A. branch; B. pistillate cymule; C staminate pleiochasium with flowers; D. fruit (Chagas - holotype). E-J. D. heterobractea - E. branch; F. involucral bract; G. staminate flower; H. pistillate flower; I. fruit; J. seed (Egler, W.A. 1482). K-P. D. juruana - K. branch; L. involucral bract; M. resiniferous gland and staminate buds; N. staminate flower; O. pistillate flower; P. pistillate sepals (F-L Quinet, A. et al. 1781). Q-T. D. liesneri- Q. branch; R. staminate pleiochasium with a staminate flower; S. pistillate flower; T. fruit (Poole, J.M. 1942)

Twining vine. Leaves simple, petiolar stipules 3-4 $\mathrm{mm}$ long, in pairs, persistent, linear-lanceolate, reflexed; petiole $0.6-2 \mathrm{~cm}$ long, glabrous to slightly pubescent; leaf blade, unlobed, $5-8 \times 1-2.5 \mathrm{~cm}$, lanceolate (usually with 2-3 lateral lobes in the same individual), base cordate to hastate, apex acuminate, margin serrate-glandular; abaxial and adaxial surfaces hirsutous; chartaceous, venation actinodromous to campylodromous; primary veins 4 (5); stipels $2,1-1.3 \mathrm{~mm}$ long, lanceolate-linear, persistent. Pseudanthium axillary, peduncle $1-3.5 \mathrm{~mm}$ long; involucral bracts $3-10 \times 0.8-1 \mathrm{~mm}$, stipuliform, cream-white, strigose on the adaxial surface, glabrous on the abaxial surface, apex acute to acuminate, base obtuse to rounded, margin entire, primary veins 1; bracteal stipule 4, 2-3 mm long, lanceolate. Staminate pleiochasium 9-16-flowered, peduncle $0.5-4 \mathrm{~mm}$ long, pubescent; staminate bracteoles 4, 2.5-3 ×0.8-1 mm, deltoid, free, adaxial surface hirsutous, abaxial surface glabrous; resiniferous glands absent. Staminate flowers, articulated pedicel 1-2 mm long; pedicel 1-5 mm long; sepals 4, 1.5-2 $\times 1-1.5 \mathrm{~mm}$, lanceolate; stamens $8-12$, staminal tube $0.3-0.5 \mathrm{~mm}$ long; anthers bithecate, rimose. Pistillate cymule 3-flowered, peduncle 2-3 $\mathrm{mm}$ long, hirsutous; pistillate bracteoles $3,1.5-5.5 \times 0.5-1.5 \mathrm{~mm}$, lanceolate, free, adaxial surface hirsutous, abaxial surface glabrous, margin entire. Pistillate flowers, pedicel $0.8-2 \mathrm{~mm}$ long; sepals 6 , 4-4.5 × 0.4-0.7 mm, entire, linear-lanceolate, hirsutous; ovary 1-1.5 mm diam, densely hirsutous, stylar column 4-7 mm long, obovate, apex rounded. Capsule 6-9 $\mathrm{mm}$ diam, light-brown, hirsutous, pistillate sepals not present. Seed 0.6-4 mm diam, subspherical, smooth, brown with dark brown macules. 
Distribution, habitat, and conservation status: Brazil (Webster \& Armbruster 1991; Armbruster 1996). This species occurs in the North Region (Amazonas and Pará; Figure 4I) and is endemic to the Brazilian Amazon (Webster \& Armbruster 1991; Armbruster 1996; Pereira-Silva et al. 2020a). It occurs mainly in secondary forests (capoeira), near sea level to $676 \mathrm{~m}$. According to IUCN (2019) criteria, the species is designated as Endangered (EN) under sub-criteria B2ab(ii,iv), due to its $\mathrm{AOO}$ of $16.000 \mathrm{~km}^{2}$ and found in only three locations (see Table 1). The environments where the species occurs are suffering great loss of habitat, as well as strong anthropic pressure (e.g., deforestation and urbanization).

Phenology: Flowers and fruits from March to December (Brazilian Amazon).

Taxonomic Notes: Dalechampia hastata is frequently confused with $D$. gentryi. They can be distinguished using the characters mentioned in the comments under the latter species.

Selected Material: BRAZIL. AMAZONAS: Manaus, Igarapé da Cachoeira, 245'S, 60¹6'W, 25.X.1954, fi., fr., W.A. Rodrigues 249 (INPA); rio Arara, 5'26'S, 6007'W, 29.IV.1973, fl., fr., A.A. Loureiro et al. (INPA37869). PARÁ. Porto Trombetas, $1^{\circ} 23^{\prime}$ 'S, $56^{\circ} 28^{\prime}$ W, 4.V.1988, fl., O.H. Knowles 1182 (INPA); Faro, $0^{\circ} 24^{\prime}$ 'S, 59 $42^{\circ}$ 'W, 26.VIII.1907, fl., fr., A. Ducke (MG8515).

Dalechampia heterobractea Armbr., Syst. Bot. 21(2): 226-229. 1996. Type: GUYANA. Mazaruni Station: K.C. Sandwith 1565 (holotype K000600713!; isotypes BM000554400!, G00434762!, NY00076948!, P00712321!, U0007968!).

Figure 6E-J

Twining vine. Leaves simple, petiolar stipule $3-7 \mathrm{~mm}$ long, in pairs, persistent, lanceolate; petiole 4-9 $\mathrm{cm}$ long, hirsutous; leaf blade, unlobed, 6-19 $\times 5-15.5 \mathrm{~cm}$, ovate, base short cordate, apex slightly acuminate to acute, margin serrate, adaxial surface sericeous, abaxial surface pubescent; chartaceous, venation campylodromous; primary veins 3 (-5); stipels 2, 1.5-2 mm long, lanceolate, persistent. Pseudanthium axillary, 1-2 fertile axes, peduncle 3-7.5 cm long; involucral bracts dimorphic, unlobed, bottom/proximal 10-16 $\times 7-11 \mathrm{~mm}$, whitish, lanceolate-ovate, strigulose, base cuneate, apex acute, margin glandularserrate, primary veins 3 , prominent, upper/distal 2.5-5 $\times 1-2 \mathrm{~mm}$, green, lanceolate, inconspicuous (deciduous), strigulose, base cuneate, apex acute, margin entire, venules $2(-3)$ striate; bottom/proximal bracteal stipules 2, 2.5-3.5 × 1-1.5 mm, linear-lanceolate, upper/distal 2, 2-3 $\times 1-2 \mathrm{~mm}$, linear-lanceolate. Staminate pleiochasium 6-10-flowered; peduncle ca. $2.5 \mathrm{~mm}$ long, sparsely pubescent; staminate bracteoles 4 , $2-3 \times$ ca. $1 \mathrm{~mm}$, ovate, free, adaxial and abaxial surfaces pubescent; resiniferous glands absent. Staminate flowers, articulated pedicel ca. 0.5 $\mathrm{mm}$ long; pedicel 2-3 mm long; sepals 4, 2-3 × 1-1.5 mm, obovate; stamens $10-15$, staminal tube $1-2 \mathrm{~mm}$ long; anthers bithecate, rimose. Pistillate cymule 3-flowered, peduncle $0.5-1 \mathrm{~mm}$ long, pubescent; pistillate bracteoles $3,2-3.5 \times 1.5-3.5 \mathrm{~mm}$, ovate to lanceolate, connate, adaxial and abaxial surfaces strigose, margin entire. Pistillate flowers, pedicel 1-2 mm long; sepals 6, 2.5-3.5 × ca. $1 \mathrm{~mm}$, entire, lanceolate, densely strigose; ovary $2-3 \mathrm{~mm}$ diam, densely strigose; stylar column 4-9 mm long, oblanceolate, apex obtuse-lanceolate. Capsule 8-8.5 mm diam, vinegar brown, strigose, with small persistent pistillate sepals (deciduous) and stylar column. Seed 3.5-4 mm diam, subspherical, smooth, light brown with dark brown macules.
Distribution, habitat, and conservation status: Brazil, Guyana, French Guiana, Suriname, and Venezuela (Armbruster 1996, 1999; Gillespie \& Armbruster 1997). In Brazil, it is restricted to the Brazilian Amazon (Amapá, Amazonas and Pará; Figure 7A) (Pereira-Silva et al. 2020a). It occurs mainly in flooded locations and terra firme forest, especially on sites with sandy soil, and may also occur in preserved brush or woodland, near sea level to $220 \mathrm{~m}$. According to IUCN (2019) criteria, the species is designated as Near Threatened (NT), due to its EOO of 857,330.005 $\mathrm{km}^{2}$ (see Table 1). The species occurs in flooded locations and terra firme forest, especially on sites with sandy soil, and may also occur in preserved brush or woodland with different collections and with distribution $\left(\mathrm{EOO}=857,330.005 \mathrm{~km}^{2}\right)$. However, the environments where the species occurs are suffering great loss of habitat, as well as strong anthropic pressure (e.g., trails and waterfalls in Presidente Figueiredo/AM). It occurs close to at least one Conservation Units (Ecological Station of Jari located in the states of Amapá and Pará, with territory distributed by the municipalities of Almeirim, Laranjal do Jari and Mazagão), but with a single population severely fragmented and the other known populations they are disjoint across countries. In this way, the species is considered to be Near Threatened (NT) of extinction. If habitat loss continues and the extent of occurrence decreases, the species may be considered to be threatened with extinction.
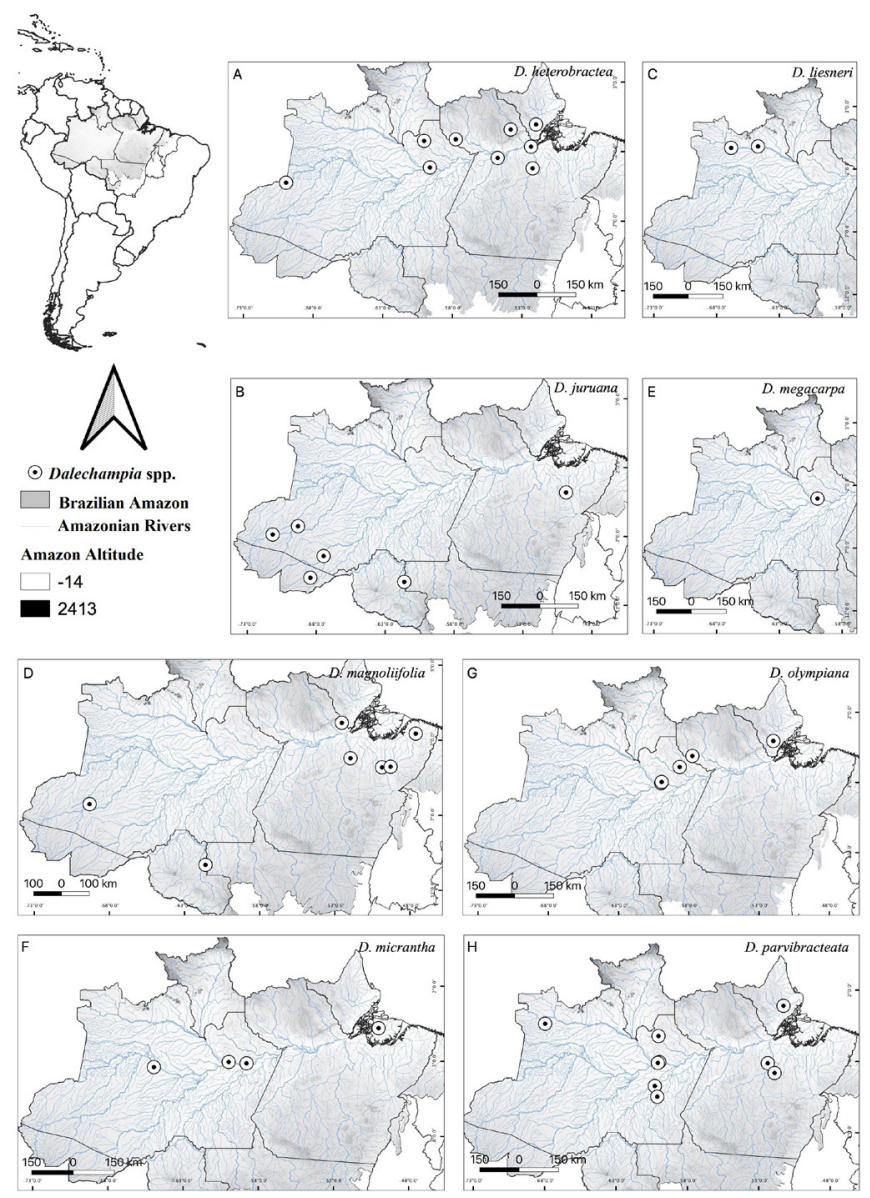

Figure 7. Geographic distribution of Dalechampia species found in Brazilian Amazon. A. Dalechampia heterobractea, B. D. juruana, C. D. liesneri, D. D. magnoliifolia, E. D. megacarpa, F. D. micrantha, G. D. olympiana and H. D. parvibracteata. 
Phenology: Flowers and fruits from May to October (Brazilian Amazon).

Taxonomic Notes: Dalechampia heterobractea is usually identified as $D$. parvibracteata due to the ovate leaves with campylodromous venation. However, these species are distinguished by the following: leaves with short cordate base ( $v s$. sharpy cordate in D. parvibracteata), membranous ( $v s$. chartaceous), slightly serreate margin ( $v s$. denticulate), primary veins 3-5 (vs. primary veins 7 ), and stiples $1.5-2 \mathrm{~mm}$ long ( $v s$. occasionally with almost inconspicuous stipels, $0.5-1 \mathrm{~mm}$ long.); involucral bracts dimorphic, inferior/proximal, lanceolate-ovate; superior/distal, lanceolate ( $v s$. monomorphic, triangular-lanceolate, stipuliform); pistillate sepals $2.5-3.5 \mathrm{~mm}$ long, densely strigose ( $v s$. 4-5 mm long, glabrous to slightly pubescent); and stylar column apex obtuse-lanceolate ( $v s$. rounded).

Selected Material: BRAZIL. AMAPÁ: Oiapoque, $3^{\circ} 48^{\prime}$ 'S, $51^{\circ} 53^{\prime} \mathrm{W}, 7 . \mathrm{VIII} .1960$, fl., fr., H.S. Irwin et al. 47396 (paratypes: IAN!, NY, RB!). AMAZONAS: Presidente Figueiredo, $2^{\circ} 01^{\prime} \mathrm{S}, 60^{\circ} 01^{\prime} \mathrm{W}$, 11.XII.2007, fl., fr., M.A.S. Costa et al. 1029 (INPA, MG). PARÁ: Almerim, 0³0'S, 5240’W, 14.XI.1986, fl., M.J. Pires \& N.T. Silva da 1449 (INPA, MO).

Dalechampia juruana Ule, Verh. Bot. Vereins Prov. Brandenburg 50: 83. 1909. Type: BRAZIL. Amazonas: rio Juruá, E.H.G. Ule 5256 (lectotype MG005228!, designated by Mendes et al. 193: 2019; isolectotypes G00434757!, HBG516386!).

Figure 6K-P; Figure 3E

Twining vine. Leaves compound, petiolar stipules 5-8 $\mathrm{mm}$ long, in pairs, persistent, elliptical; petiole $5.5-13 \mathrm{~cm}$ long, tomentose; leaf blade, 3-foliolate; middle leaflet 10-13 × 5-6.5 cm, elliptic-lanceolate, base obtuse, apex attenuate; lateral leaflets $8-11.6 \times 4-5.5 \mathrm{~cm}$, obliqueovate, apex attenuate; margin slightly serrate-ciliate, adaxial surface pubescent, abaxial surface sparsely pubescent; membranaceous, venation eucamptodromous; primary veins $3(-5)$; stipels $2,1-3 \mathrm{~mm}$ long, deltoid, persistent. Pseudanthium axillary or terminal, peduncle ca. $1.5 \mathrm{~cm}$ long; involucral bracts $1-1.3 \times 0.8-1 \mathrm{~cm}$, greenish, obdeltoid, adaxial and abaxial surfaces pubescent, apex 3 -toothed, base attenuate, margin dentate-ciliate, primary veins 3 , bracteal stipules 4, 6-7 long, oblong. Staminate pleiochasium 9-flowered, peduncle ca. $2 \mathrm{~mm}$ long, sparsely pubescent; staminate bracteoles 4 , ca. $2 \times 3-3.5 \mathrm{~mm}$, ovate, connate, adaxial and abaxial surfaces pubescent; resiniferous glands 2-2.5 $\times 2.5-3 \mathrm{~mm}$, laminar. Staminate flowers, articulated pedicel ca. $1.5 \mathrm{~mm}$ long; pedicel $0.8-1 \mathrm{~mm}$ long; sepals $12,1.5-2 \times 0.5-0.8$ $\mathrm{mm}$, lanceolate; stamens ca. 12, staminal tube ca. $1 \mathrm{~mm}$ long; anthers bithecate, rimose. Pistillate cymule 3-flowered, peduncle ca. $1 \mathrm{~mm}$ long, pubescent; pistillate bracteoles 3, 3.5-4 × 5-7 mm, ovate, connate, adaxial and abaxial surfaces strigose, margin ciliate-glandular. Pistillate flowers, pedicel ca. $1 \mathrm{~mm}$ long; sepals $6,3-4 \times$ ca. $1 \mathrm{~mm}$, pinnatifidlaciniate, pubescent, without stipitate-glandular trichomes; ovary $2 \mathrm{~mm}$ diam., sericeous-tomentose; stylar column 2-3 mm long, cylindrical, apex slightly enlarged-clavate. Capsule $7-8 \mathrm{~mm}$ diam, rusty-tomentose, with small persistent pistillate sepals and stylar column. Seed $3 \mathrm{~mm}$ diam, globose, rugose, light brown with reddish-brown macules.

Distribution, habitat, and conservation status: Bolivia, Brazil, Colombia, Ecuador [new occurrence], Peru, and Venezuela (Webster \& Armbruster 1991). In Brazil, it is restricted to the Brazilian Amazon (Acre, Amazonas, Pará and Rondônia; Figure7B) (Pereira-Silva et al. 2020a). It occurs mainly in forest or riparian borders, near sea level to $257 \mathrm{~m}$. According to IUCN (2019) criteria, the species is designated as Least Concern (LC), due to its EOO of 4,129,027.563 $\mathrm{km}^{2}$ (see Table 1). Although, if we consider the occurrence only in Brazil, known in 8 localities, the taxon can be designated as Vulnerable (VU) under criteria subcriteria B2ab(i,ii,iii,iv) because some populations are in place with high human pressure.

Phenology: Flowers and fruits from February to December (Brazilian Amazon).

Taxonomic Notes: Dalechampia juruana is superficially similar to D. sylvestris because it has leaves that are 3-foliolate and membranous, with eucamptodromous venation. However, D. juruana has the following: middle leaflets elliptic-lanceolate, $10-13 \times 5-6.5 \mathrm{~cm}(v s$. elliptic, $6.5-8.5 \times 2-3$ in $D$. sylvestris), petiole $5.5-13 \mathrm{~cm}$ long. (vs. $1-5 \mathrm{~cm}$ long.); pseudathium axillary ( $v s$. axillary or terminal), peduncle 5.5-7.5 cm long. ( $v s .1 .5 \mathrm{~cm}$ long.); involucral bracts $1-1.3 \times 0.8-1 \mathrm{~cm}$ (vs. 3-5 × 3.5-7.2 cm), obdeltoid ( $v s$. widely obovate), apex 3-lobed (vs. apex deeply 3-lobed), base attenuate (vs. truncate), primary veins 3 (vs. 5); pistillate sepals pinnatifid ( $v s$. entire); and stylar column apex

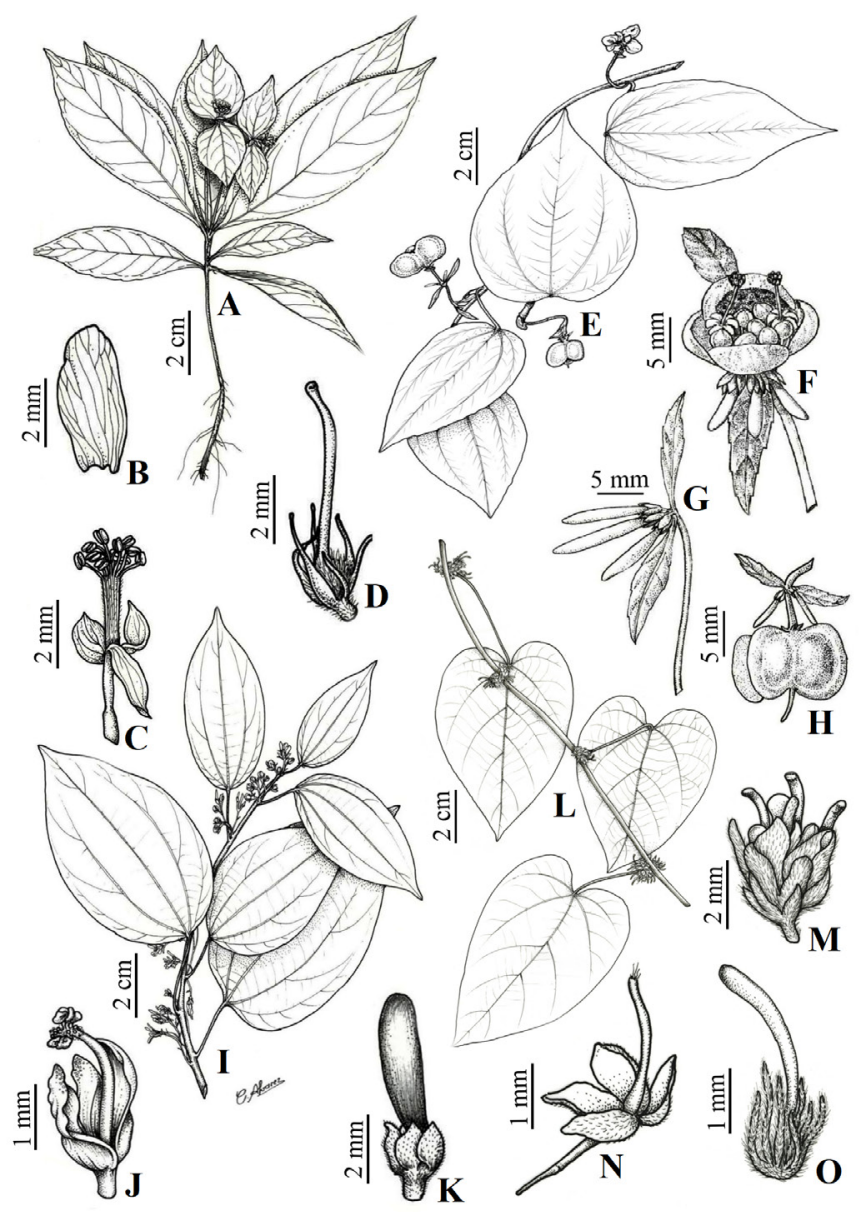

Figure 8 -A-D. Dalechampia magnoliifolia -A. branch; B. staminate bracteole; C. staminate flower; D. pistillate flower (A, B Hiliu-Borges, A.L. \& Rosario, C.S. 1769; C-D Goeldi, A. (MG7788)). E-H. D. megacarpa - E. branch; F. pseudanthium; G. pistillate cymule; H. fruit (Rodrigues, W. \& Coelho, D. 1801). I-K. D. micrantha - I. branch; J. staminate flower; K. pistillate flower (Ducke (MG7891)). L-O. D. olympiana - L. branch; M. set of pleiochasium and cymule; N. staminate flower; O. pistillate flower (Rodrigues 225, isotype). 
slightly enlarged-clavate ( $v s$. slightly dilated-obovate). Dalechampia juruana is illustrated here for the first time.

Nomenclatural notes: For Dalechampia juruana, two different lectotypes were designated in different publications. The two lectotypifications were published seven days apart. The article by Athiê-Souza et al. (2019) was accepted for publication on 20 June and published on 9 September, while the manuscript by Mendes et al. (2019) was accepted on August 14th and published on September 2nd. Considering the publication priority of Art. 9.19 of ICN (Turland et al. 2018), the specimen Ule 5256 deposited at MG (barcode 005228), and selected by Mendes et al. (2019), should be the lectotype.

Selected Material: BRAZIL. ACRE: Rio Branco, 9²7'S, 6959'W, XII.1943, fl., J.E. Wilde \& J.T. Baldwin 53 (NY). AMAZONAS: Limoeiro, 6054'S, 71º8'W, 25.XI.1977, fl., fr., C. Damião 2763 (INPA, MO). PARÁ: Tucuruí, 349'S, 49³9’W, 14.XII.1979, fr., M.F.F. Silva, et al. 373 (INPA, MG). RONDÔNIA: Rio machado, $8^{\circ} 05^{\prime} \mathrm{S}, 63^{\circ} 11^{\prime} \mathrm{W}$, II.1981, fl., M. Goulding 1263 (INPA, MG).

Dalechampia liesneri Huft. Ann. Missouri Bot. Gard 76: 1078. 1989. Type: VENEZUELA. Territorio Federal Amazonas: Depto. Atures, stream $0.5-2 \mathrm{~km}$ E of Río Coro-Coro, W of Serranía de

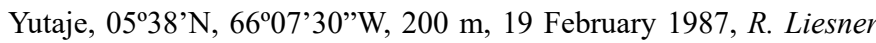
\& B.K. Holst 21244 (holotype MO3430505!; isotypes U0001903!, VEN263240!).

\section{Figure 6Q-T}

Twining vine. Leaves simple, petiolar stipule 3-4 mm long, in pairs, persistent, lanceolate; petiole $9.5-10 \mathrm{~cm}$ long, pubescent; leaf blade, unlobed, $9.5-13 \times 7-10 \mathrm{~cm}$, ovate to deltoid, base cordate, apex acuminate, margin discreetly denticulate, adaxial and abaxial surfaces glabrous; membranaceous, venation campylodromous; primary veins 5; stipels 2, inconspicuous, deltoid, persistent. Pseudanthium axillary, peduncle 1-4 cm long; involucral bracts $2-4 \times$ ca. $0.5 \mathrm{~mm}$, inconspicuous, green, stipuliform, slightly strigose on adaxial and abaxial surfaces, apex acute, base slightly truncate, margin slightly serrate, primary veins 3 ; bracteal stipule $4,1.5-2 \mathrm{~mm}$ long, lanceolate. Staminate pleiochasium 8-flowered; peduncle ca. $2.5 \mathrm{~mm}$ long, strigose; staminate bracteoles $4,2-4 \times 1-1.5 \mathrm{~mm}$, lanceolate, connate, adaxial and abaxial surfaces pubescent; resiniferous glands absent. Staminate flowers, articulated pedicel 1-1.5 mm long; pedicel 2-5 mm long; sepals $5,2-2.5 \times 1-1.5 \mathrm{~mm}$, ovate, sparsely hirsutous; stamens $8-10$, staminal tube 4-5 mm long, anthers bithecate, rimose. Pistillate cymule 3-flowered, peduncle 2-2.5 mm long, pubescent; pistillate bracteoles 4 (-5), 2.5-3 × 0.8-1 mm, lanceolate, connate, adaxial and abaxial surfaces strigose, margin entire. Pistillate flowers, pedicel ca. $1 \mathrm{~mm}$ long; sepals $6,2.5-3 \times 0.8-1 \mathrm{~mm}$, linear-lanceolate, sparsely pubescent; ovary ca. $2 \mathrm{~mm}$ diam, strigose, stylar column 13-15 mm long, linear, apex uniformly cylindrical. Capsule 6-7 $\mathrm{mm}$ diam, brown, slightly pubescent. Seed ca. $4 \mathrm{~mm}$ diam, ovoid to subglobose, smooth, light brown with dark brown macules.

Distribution, habitat, and conservation status: Brazil and Venezuela (Armbruster 1996). In Brazil, it occurs in the North Region (Amazonas; Figure 7C) (Pereira-Silva et al. 2020a). In the study area, the collections are from secondary forest, and in the Brazilian Amazon this is still a poorly collected species; there are only two very old collections. It is found near sea level to $776 \mathrm{~m}$. The species is only known from three old collections from sites that are difficult to access. The populations may or may not be well preserved, so following the IUCN (2019) criteria, the species is designated as Data Deficient (DD) (see Table 1).

Phenology: Flowers and fruits from July to December (Brazilian Amazon).

Common name: "Cansanção."

Taxonomic Notes: Dalechampia liesneri differs from other species in this study by the following set of characters: pseudanthium with peduncle 1-4 cm long, staminate pleiochasium 8-flowered with peduncle ca. $2.5 \mathrm{~mm}$ long, staminate flowers with articulated pedicel $1-1.5 \mathrm{~mm}$ long and pedicel $2-5 \mathrm{~mm}$ long, as well as, stamens $8-10$, and stylar column 13-15 mm long, and apex uniformly cylindrical.

Selected Material: BRAZIL. AMAZONAS: São Gabriel da Cachoeira, Serra Curicuriari, 0²0'S, 6650'W, 10.VII.1979, fr., J.M. Poole 1942 (INPA); Porto Curucuhy [Porto Curicuriari], rio Negro, 0¹2’S, 66²0’W, 5.X.1945, fl., fr., R.L. Fróes 21099 (NY).

Dalechampia magnoliifolia Müll. Arg., Linnaea 34: 219. 1865. Type: BRAZIL. Pará: C.F.P. von Martius s.n (lectotype M0233666!, designated by Mendes et al. 191: 2019; isolectotypes G00236455!, K001096084!, M0233667!, M0233668!, M0233669!).

Figure 8A-D; Figure 3F

Subshrubs erect. Leaves simple, petiolar stipules $0.2-0.8 \mathrm{~mm}$ long, in pairs, persistent, triangular-ovate; petiole $0.2-0.6 \mathrm{~mm}$ long, sericeous to glabrescent, 3-4 glands at base of limbus; leaf blade, unlobed, 13-22 × 3-7 cm, elliptical-lanceolate, base cuneate, apex acute-acuminate, margin sinuous, adaxial and abaxial surfaces glabrous; chartaceous, venation camptodromous; primary vein 1; stipels not present. Pseudanthium axillary or terminal, peduncle $3-3.5 \mathrm{~cm}$ long; involucral bracts $3.5-4 \times 2.5-3.5 \mathrm{~cm}$, pink, triangular-ovate, adaxial surface strigose, abaxial surface glabrous, apex acuminate, base truncate, margin denticulate, primary veins 3 , bracteal stipules $4,3-8 \mathrm{~mm}$ long, ovate. Staminate pleiochasium 10-flowered; peduncle $2.5-3 \mathrm{~mm}$ long, slightly hirsutous; staminate bracteoles $3,3-4 \times 2.5-3 \mathrm{~mm}$, broadelliptical, connate, adaxial and abaxial surfaces pubescent; resiniferous glands $3-3.5 \times 7.5-8 \mathrm{~mm}$, laminar, grouped into $6-8$ blades, apex cylindrical-glandulous. Staminate flowers, articulated pedicel $2-2.5 \mathrm{~mm}$ long; pedicel 2-3 mm long; sepals 6, 2.5-3 $\times 0.1-0.2 \mathrm{~mm}$, triangularlanceolate, slightly strigose; stamens 10 , branched, staminal tube 3-3.5 $\mathrm{mm}$ long; anthers bithecate, rimose. Pistillate cymule 3-flowered, peduncle $0.1-0.2 \mathrm{~mm}$ long, hirsutous; pistillate bracteoles $3,3-4.5 \times$ $3.5-4 \mathrm{~mm}$, lanceolate or widely-ovate, connate, adaxial and abaxial surfaces strigose, margin ciliate. Pistillate flowers, pedicel ca. $2 \mathrm{~mm}$ long; sepals 5, 2.5-3.5 × 0.1-1.3 mm, linear-lanceolate, strigose; ovary $2 \mathrm{~mm}$ diam, strigose-hispid; stylar column 5-8 mm long, linear, apex uniapertured-papillose. Capsule and seed not seen.

Distribution, habitat, and conservation status: Brazil, Ecuador [new occurrence], Guyana [new occurrence], Peru, and Venezuela [Bolivar] (Webster \& Armbruster 1991). In Brazil, it occurs in the Central-West (Mato Grosso) and North (Amazonas, Pará, Rondônia; Figure 7D) regions (Webster \& Armbruster 1991; Pereira-Silva et al. 2020a). In the study area, this species is found in rainforest, mainly by rivers, near sea level to $146 \mathrm{~m}$. It is often cultivated as an ornamental. According to IUCN (2019) criteria, the species is designated as Least Concern (LC), due to its EOO of 4,479,894.441 km² (see Table 1).

Phenology: Flowers mainly from January to October (Brazilian Amazon). 
MENDES, J.C.R. et al.

Taxonomic Notes: Dalechampia magnoliifolia is one of the easiest species to recognize. It is the only subshrub of the genus in northern Brazil. Beyond this, the leaf blade is elliptic-lanceolate with sinuate margins and pinnate venation. Other notable characteristics are the triangular-ovate involucral bracts, staminate flowers with 10 branched stamens, and laminar resin gland with a cylindrical-glandular apex.

Selected Material: BRAZIL. AMAZONAS: Juruá, 329'S, 660', IX.1901, fl., E.H.G. Ule 5865 (G, K, MG, MO). PARÁ: Tucuruí, 348'S, 49³9'W, 14.IX.2000, fl., A.L. Ilkiu-Borges \& C.S. Rosário 1769 (MG); São Miguel do Guamá, 1³6'S, 47²2'W, X.1906, fl., A. Goeldi (MG7788). RONDÔNIA: rio Jiparaná, 1055'S, 61 $57^{\circ}$ 'W, 20.X.1979, fl., J.L. Zaruchi et al. 2784 (INPA, MG, NY, RB).

Dalechampia megacarpa Armbr., Brittonia 41: 47. 1989. Type: VENEZUELA. Estado Bolivar: Dtto. Roscio, 3-7 km NW San Isidro (Km 88), W.S. Armbruster et al. 85-115 (holotype MO3891231!; isotype NY0026302!).

Figure 8E-H

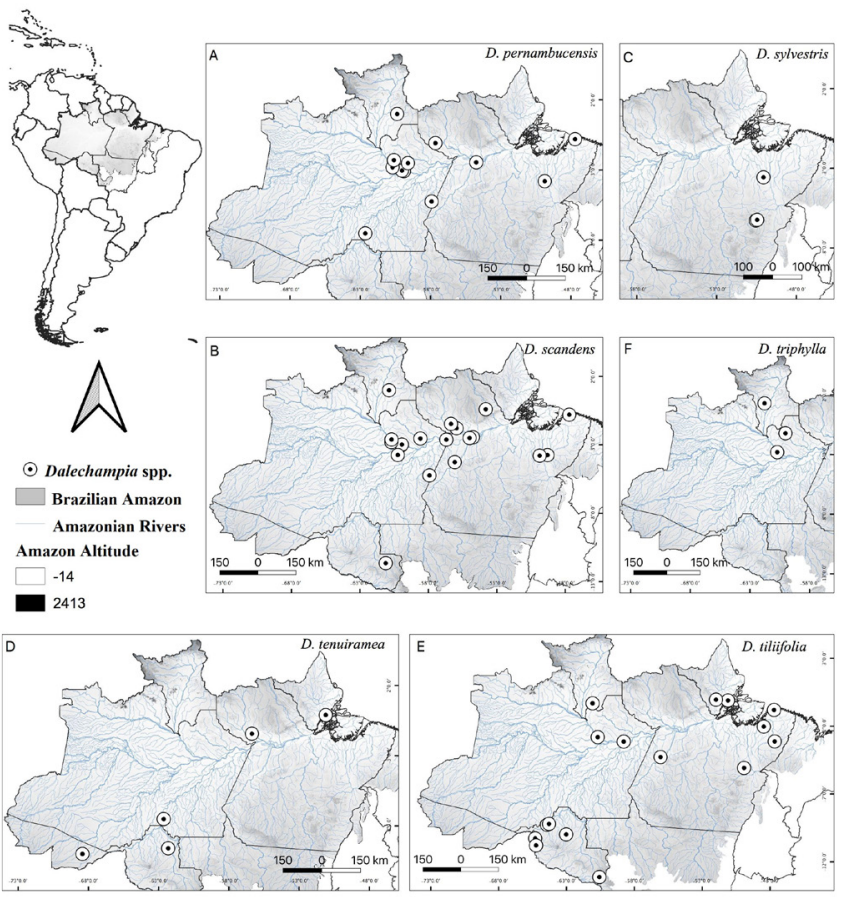

Figure 9- Geographic distribution of Dalechampia species found in Brazilian Amazon. A. Dalechampia pernambucensis, B. D. scandens, C. D. sylvestris, D. D. tenuiramea, E. D. tiliifolia and F. D. triphylla.

Twining vine. Leaves simple, petiolar stipules $2.5-5 \times 1-1.5$ $\mathrm{mm}$, in pairs, deciduous, lanceolate to ovate; petiole $2.5-10 \mathrm{~cm}$ long, pubescent; leaf blade, unlobed, 7-27 × 5-20 cm, ovate, base truncate, apex acuminate, margin discreetly dentate, with glands, abaxial surface strigose and tomentose, adaxial surface glabrous; chartaceous, venation campylodromous; primary veins 5 ; stipels $2-4$, inconspicuous, deltoidglandular, persistent. Pseudanthium axillary, peduncle $1.5-3 \mathrm{~cm}$ long; involucral bracts $1-2 \times 0.4-0.6 \mathrm{~cm}$, green, lanceolate to oblanceolate, adaxial surface glabrous, abaxial surface sparsely strigose, apex acute, base attenuate, margins revolute, glandular-undulate, primary veins
1 (-3); bracteal stipules 4, 2.5-4 cm long, ovate-falcate. Staminate pleiochasium 7-9-flowered, peduncle $2-4 \mathrm{~mm}$ long, densely strigose; staminate bracteoles 4, 2.5-3 $\times 4.5-5.5 \mathrm{~mm}$, obovate, connate, adaxial and abaxial surfaces pubescent; resiniferous glands $2-3.5 \times 0.1-2.5$ $\mathrm{mm}$, laminar, with greenish-blue resin. Staminate flowers, articulated pedicel 1-2.5 mm long; pedicel 1-4 mm long; sepals 4-6, 1-2 × 0.8-1 $\mathrm{mm}$, lanceolate-ovate; stamens $8-20$, staminal tube $1.5-2 \mathrm{~mm}$ long; anthers bithecate, rimose. Pistillate cymule 3 -flowered, peduncle sessile; pistillate bracteoles $3,1-2 \times 1.5-3 \mathrm{~mm}$, obovate-elliptical, connate, adaxial and abaxial surfaces strigose, margin erose-ciliate. Pistillate flowers, pedicel $0.3-1 \mathrm{~mm}$ long; sepals $6,1-1.5 \times 0.4-1 \mathrm{~mm}$, entire, ovate, margin ciliate, without stipitate-glandular trichomes; ovary ca. 0.7-1.5 mm diam, hirsutous, stylar column 4-6 cm long, linear, apex foveolate. Capsule 5-5.5 cm diam, greenish-brown, sparsely strigose, involucral bracts present. Seeds $9-11 \mathrm{~mm}$ diam, flattened-oval, smooth, dark brown with gray macules.

Distribution, habitat and conservation status: Brazil and Venezuela (Webster \& Armbruster 1991; Gillespie \& Armbruster 1997). In Brazil, it has been registered in the North Region (Amazonas; Figure 7E) (Gillespie \& Armbruster 1997); Pereira-Silva et al. 2020a). In the study area, this species is poorly known and represented by only one old collection. It occurs near sea level to $72 \mathrm{~m}$. According to IUCN (2019) criteria, the species is designated as Endangered (EN)) under sub-criteria B2ab(i,ii,iv), due to its AOO of $12.000 \mathrm{~km}^{2}$ and found in only three locations (see Table 1). It's endangered because there are probably few mature individuals. At least one of the subpopulation is found near Manaus that has a high degree of deforestation.

Phenology: Flowers and fruits from September to December (Brazilian Amazon).

Taxonomic Notes: Dalechampia megacarpa differs from other species in the study area by pistillate cymule with sessile and pistillate flowers with short pedicels (0.3-1 mm long); size of the capsules (5-5.5 $\mathrm{cm}$ diam), and seeds (9-11 $\mathrm{mm}$ diam). It is notable that the fruits and seeds of $D$. megacarpa are larger compared to the other species of the genus that occur in Amazonia, Brazil.

Examined Material: BRAZIL. AMAZONAS: Manaus, 253'S, 60²' 'W, 30.IX.1960, fl., fr., W. Rodrigues \& D. Coelho 1801 (INPA).

Dalechampia micrantha Poepp., Nov. Gen. sp. pl. 3:19, 1845. Lectotype (first-step, designed by Webster \& Armbruster 105: 1991): BRAZIL. Amazonas. Ega (Tefé), E.F. Poeppig 2807 (lectotype W; isolectotype $\mathrm{K}$ ); Lectotype (second-step, here designated): BRAZIL. Amazonas. Ega (Tefé), E.F. Poeppig 2807 (lectotype W0023456!, isolectotypes F0056226!, G00209283!, P00640224!, W104762! W0623455! W120959! W214875!).

Figure $8 \mathrm{I}-\mathrm{K}$

Twining vine. Leaves simple, petiolar stipules $2-3 \mathrm{~mm}$ long, in pairs, deciduous, triangular-lanceolate; petiole $2-5 \mathrm{~cm}$ long, strigose; leaf blade, unlobed, 8-15 $\times 4-12 \mathrm{~cm}$, oblong-ovate, base subtruncate to rounded, apex cuspidate-acuminate, margin denticulate to slightly denticulate, glandular, adaxial surface slightly pubescent, abaxial surface slightly strigose; chartaceous, venation campylodromous; primary veins 5 ; stipels 2, 2-3 $\mathrm{mm}$ long, acicular, persistent. Pseudanthium axillary, axes $2-3$, peduncle 1.5-2 cm long; involucral bracts $2-3 \times 1.5-2 \mathrm{~mm}$, green, stipuliform, inconspicuous, strigose on the adaxial and abaxial surfaces, apex acute, base obtuse, margin denticulate, primary veins 3 , bracteal stipules 4, 2-3 mm long, 
linear-lanceolate. Staminate pleiochasium 13-flowered, arranged in 4 fertile axes; peduncle ca. $1.5 \mathrm{~mm}$ long, sparsely strigose; staminate bracteoles 4 , 2-2.5 $\times 3-4 \mathrm{~mm}$, obovate-spatulate, connate, adaxial and abaxial surfaces glabrous; resiniferous gland absent. Staminate flowers, articulated pedicel ca. $1 \mathrm{~mm}$ long; pedicel ca. $1.5 \mathrm{~mm}$ long; sepals 3, 2.5-3 $\times 0.8-1 \mathrm{~mm}$, lanceolate, connate, glabrous; stamens 4-8, staminal tube ca. $3 \mathrm{~mm}$ long; anthers bithecate, rimose. Pistillate cymule 3-flowered, peduncle ca. 1.5 mm long, pubescent; pistillate bracteoles $5(-6), 2.5-4 \times 3-3.5 \mathrm{~mm}$, linearlanceolate, connate, adaxial and abaxial surfaces glabrous, margin ciliate. Pistillate flowers, pedicel ca. $1 \mathrm{~mm}$ long; sepals 5-6, 2.5-3 $\times 0.5-1.2 \mathrm{~mm}$, entire, lanceolate-ovate, deciduous; ovary 1-2.5 mm diam, sericeous-strigose; stylar column ca. $9 \mathrm{~mm}$ long, linear-foveolate, apex truncate. Capsule 0.6-1 $\mathrm{mm}$ diam, black, strigose, pistillate sepals deciduous at maturation. Seed 5 mm diam, subspherical, smooth, dark brown to black with gray macules.

Distribution, habitat, and conservation status: Brazil, French Guiana, Peru (Loreto), Suriname, and Venezuela (Bolivar) (Webster \& Armbruster 1991; Gillespie \& Armbruster 1997). In Brazil, it is restrited the North Region (Amazonas, Pará; Figure 7F) (Pereira-Silva et al. 2020a). In the study area, the species occurs mainly in rainforest, terra firme forest edges, and disturbed areas, near sea level to $72 \mathrm{~m}$. According to IUCN (2019) criteria, the species is designated as Least Concern (LC), due to its EOO of 2,497,274.660 $\mathrm{km}^{2}$ (see Table 1).

Phenology: Flowers and fruits from February to December (probably year-round) (Brazilian Amazon).

Taxonomic Notes: Dalechampia micrantha shows superficial morphological affinities to $D$. fragrans. These species are differentiated by the characters cited in the comments under the latter species.

Nomenclatural notes: Poeppig (1845) proposed D. micrantha but did not cite a specimen. Webster and Armbruster (1991) cited the collection Poeppig 2807 at W as the holotype, they did an inadvertent lectotypification, according to Art. 7.11 (Ex. 13) and Art. 9.10 (Ex. 11) of the ICN (Turland et al. 2018), and the first-step lectotypification. However, we found five specimens from the Poeppig 2807 in this same herbarium. According to Art. 917. of the ICN (Turland et al. 2018), we chose the specimen W0023456 to be the lectotype, respecting the indication of this herbarium by Webster and Armbruster (1991) since it is the work institution of the author of the species (Stafleu \& Cowan 1976).

Selected Material: BRAZIL. AMAZONAS: Manaus, 328'S, 6004'W, 13.V.1994, fl., fr., S.W. Armbruster \& W. Kress 94-14 (ALA, INPA). PARÁ: Anajás, $0^{\circ} 42^{\prime}$ S, 50¹1'W, 28.X.1978, fl., fr., B.V. Rabelo et al. 3647 (INPA, MO, NY).

Dalechampia olympiana Kuhlm. \& W.A. Rodrigues, Publ. Inst. Nac. Pesq. Amazônia Bot., 5: 1. 1954. Type: BRASIL. Amazonas: Manaus, W.A. Rodrigues INPA 225 (holotype INPA225!; isotype MG022661!).

Figure 8L-O

Twining vine. Leaves simple, petiolar stipules 6-10 mm long, in pairs, deciduous, oblong-lanceolate; petiole $7.5-10 \mathrm{~cm}$ long, tomentose; leaf blade, unlobed, $10-20 \times 7-13 \mathrm{~cm}$, ovate, base cordate, apex acuminate, margin serrate to denticulate, adaxial surface lanuginous, abaxial surface hirsutous; membranaceous, venation campylodromous; primary veins 3 (-5); stipels 2, subsessile $0.1-0.2 \mathrm{~mm}$ long, deltoid, persistent. Pseudanthuim axillary (in agglomerate), peduncle subsessile, ca. $0.5 \mathrm{~mm}$ long; involucral bracts 3-5 $\times$ 2.5-3 mm, greenish, stipuliform, lanceolate, glabrous on adaxial surface, lanuginous on abaxial surface, apex acute, base subcordate, margin entire, primary veins $1(-2)$; bracteal stipules $4,1-1.5 \times$ ca. $1 \mathrm{~mm}$, subovate. Staminate pleiochasium 12-flowered, peduncle ca. $3 \mathrm{~mm}$ long, tomentose; staminate bracteoles $6,2.5-3 \times$ ca. $0.5 \mathrm{~mm}$, strait-elliptical, connate, adaxial surface glabrous, abaxial surface pubescent; resiniferous gland absent. Staminate flowers, articulated pedicel ca. $1 \mathrm{~mm}$ long; pedicel 1.5-2 $\mathrm{mm}$ long; sepals 4, 1.5-2 × 0.5-0.8 mm, elliptical-ovate; stamens 9-16, staminal tube $2 \mathrm{~mm}$ long; anthers bithecate, rimose. Pistillate cymule 3 -flowered, peduncle ca. $2 \mathrm{~mm}$ long, tomentose; pistillate bracteoles $4(-5), 3-4 \times$ ca. $0.5 \mathrm{~mm}$, lanceolate, connate, adaxial surface glabrous, abaxial surface tomentose, margin ciliate. Pistillate flowers sessile; sepals 4 (-6), 3-4 × 0.5-1.5 mm, entire, free, lanceolate, tomentose, margin slightly ciliate; ovary ca. $0.5 \mathrm{~mm}$ diam, hirsute, stylar column 6-10 mm long, linear, apex truncate. Capsule ca. $18 \mathrm{~mm}$ diam, yellowish-brown, hispid, with pistillate sepals and persistent involucral bracts. Seed $4-4.5 \mathrm{~mm}$ diam, globose, rugose, dark brown with light brown macules.

Distribution, habitat and conservation status: Brazil and Guyana (Armbruster 1996; Gillespie \& Armbruster 1997). In Brazil, it is restritet the North Region (Amazonas, Amapá, Pará; Figure 7G) (Pereira-Silva et al. 2020a). In the study area, the species occurs mainly in terra firme forest, near sea level to $482 \mathrm{~m}$. According to IUCN (2019) criteria, the species is designated as Endangered (EN) under sub-criteria B2ab(i, ii, iii, iv), due to its AOO of $20.000 \mathrm{~km}^{2}$ (see Table 1). The species is known from five sites in three disjunct subpopulations (Brazil, Guyana). Although most of the collections are found in the Adolpho Ducke Forest Reserve (Manaus, Brazil) are in protected areas. Still, the protected area is subject to threats and continuous decline in habitat quality, mainly by the threats of occupation in its surroundings, which are gradually endangering the forest ecosystem. Other specimens found in streamside environments (Igarapé do Passarinho, Igarapé do Buião) in the urban center of Manaus, have already been "swallowed" by residences. Therefore, D. olympiana was considered Endangered (EN) for the mentioned reasons.

Phenology: Flowers and fruits from September to October (Brazilian Amazon).

Taxonomic Notes: Dalechampia olympiana is completely different from the other species found in the Brazilian Amazon. It can be distinguished mainly by the following: densely pilose on branches, with an orangish-ferrugine color, as well as the petiole and primary veins of leaf blade; involucral bracts nearly inconspicuous $(3-5 \times 2.5-3$ $\mathrm{mm}$ ); and subsessile (ca. $0.5 \mathrm{~mm}$ long.) pseudanthium with a cluster of flowers in the leaf axilla. This species is here illustrated in detail for the first time, since Kuhlmann \& Rodrigues (1954), when describing it, provided only a photo of the specimen.

Selected Material: BRAZIL. AMAZONAS: Manaus, $3^{\circ} 01$ 'S, 5953'W, 26.XI.1996, fl., M.J.E. Hopkins et al. 1608 (INPA, MG). AMAPÁ: Mazagão, 008'S, 5148'W, 19.XII.1984, fl., fr., B.V. Rabelo 3030 (RB, NY, MO). PARÁ: Faro, 066'S, 61º0'W, 26.VIII.1907, fl., A. Ducke (MG8515).

Dalechampia parvibracteata Lanj., Recueil Trav. Bot. Néerl. 31: 463. 1934. Type: Guyana. Upper Demerara River, fr. Sept. 1887, Jenman 4088 (lectotype K000600729!, here designated; isolectotype K000600730!).

Figure 10A-D

Twining vine. Leaves simple, petiolar stipules $3-8 \mathrm{~mm}$ long, in pairs, persistent, lanceolate; petiole 6-10 cm long, hispid; leaf blade, unlobed, 5-15 $\times 5-16.5 \mathrm{~cm}$, ovate to suborbicular, base sharpy cordate, apex cuspidate- 
acuminate, margin denticulate, adaxial surface pubescent, abaxial surface hispid; membranaceous, venation campylodromous; primary veins $5(-7)$; stipels 2, 0.5-1 mm long, linear-lanceolate, persistent. Pseudanthium axillary, peduncle $9.5-10 \mathrm{~cm}$ long; involucral bracts $3-5 \times 2-3 \mathrm{~mm}$, greenish, triangular-lanceolate, densely pubescent on adaxial and abaxial surfaces, apex acuminate, base subcordate, margin entire, primary veins 2 (-3); bracteal stipule 2, 0.6-1 mm long, linear-lanceolate. Staminate pleiochasium 9-flowered, peduncle $1.5-3 \mathrm{~mm}$ long, densely pubescent; staminate bracteoles 4, 2-3 × 1.3-2 mm, oblong-orbicular, connate, adaxial surface glabrous, abaxial surface hirsute; resiniferous gland absent. Staminate flowers, articulated pedicel 2-3 mm long; pedicel ca. $1 \mathrm{~mm}$ long, sepals 4 , $1.5-2 \times 1.5-5 \mathrm{~mm}$, entire, elliptical; stamens 15 , staminal tube $2-3 \mathrm{~mm}$ long; anthers bithecate, rimose. Pistillate cymule 3 -flowered, peduncle $0.5-1$ $\mathrm{cm}$ long, pubescent, pistillate bracteoles 2, 2.5-3 $\times 1.5-2 \mathrm{~mm}$, triangularlanceolate, connate, adaxial and abaxial surfaces pubescent, margin ciliate. Pistillate flowers, pedicel ca. 1.5-2 mm long; sepals 6, 4-5 × 1-1.5 mm, entire, ovate-linear to obovate-linear, glabrous to slightly pubescent, margin entire; ovary 2-3 mm diam, densely pubescent, stylar column 6-9 $\mathrm{mm}$ long, oblanceolate, apex rounded. Capsule 1-1.5 cm diam, blackish brown, strigose, with small persistent pistillate sepals and stylar column. Seed ca. 5 $\mathrm{mm}$ diam, globose, smooth, yellowish with wine macules.

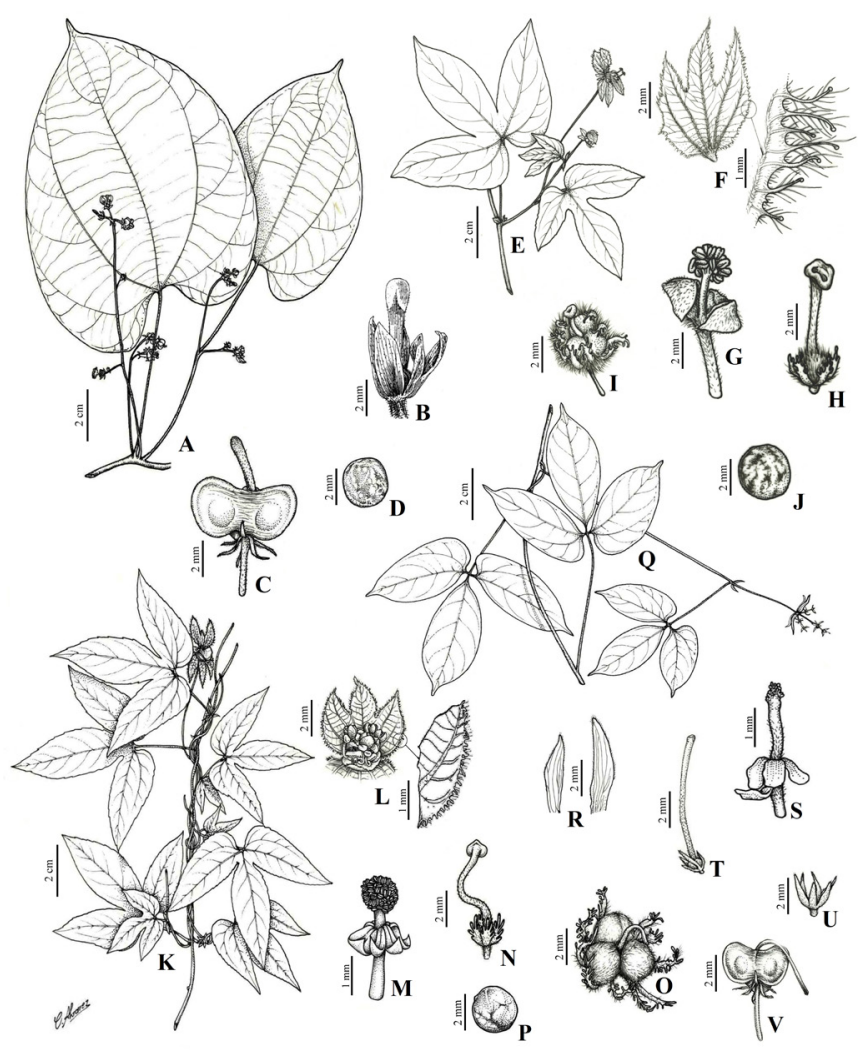

Figure 10 -A-D. Dalechampia parvibracteata -A. branch; B. pistillate flower; C. fruit; D. seed (Irwin, H.S. (MG25882)). E-J. D. pernambucensis - E. branch; F. involucral bract, detail margin fimbriate-ciliate; G. staminate flower; H. pistillate flower; I. fruit; J. seed (Assumption, S. \& Coelho, D. 43). K-P. D. scandens - K. branch; L. involucral bract, detail margin serrate-ciliate; M. staminate flower; N. pistillate flower; O. fruit with persistent sepals; P. seed (Chagas (MG21877)). Q-V. D. sylvestris - Q. branch; R. one pair of bracteal stipules (smaller and larger); S. staminate flower; T. pistillate flower; U. pistillate flower sepals; V. fruit (Silva, M.G. \& Bahia, R. 2944).
Distribution, habitat, and conservation status: Brazil, Guyana, eastern Venezuela, and Suriname (Gillespie \& Armbruster 1997). In Brazil, it is restrited the North Region (Amapá, Amazonas, Pará; Figure 7H) (Pereira-Silva et al. 2020a). The species is found in the canopy plateau and mountain slope, near sea level to 34-300 m. According to IUCN (2019) criteria, the species is designated as Least Concern (LC), due to its EOO 1,029,957.112 $\mathrm{km}^{2}$ (see Table 1).

Phenology: Flowers and fruits mainly from October to March (Brazilian Amazon).

Taxonomic Notes: Dalechampia parvibracteata is morphologically similar to $D$. heterobractea, especially because of the leaf shape (ovate) and campylodromous venation. These species can be distinguished based on the comments under the latter species.

Nomenclatural notes: Dalechampia parvibracteata was proposed by J. Lanjouw (1934) based on Jenman 4088 at K. Considering that there are two duplicates of this collection, a lectotype needed to be selected, according to Art. 9.3 of the ICN (Turland et al. 2018). Thus, the specimen K000600729 was chosen as the lectotype because it has reproductive structures and is in a good state of conservation.

Selected Material: BRAZIL. AMAPÁ: rio Oiapoque, 353'S, 5346'W, 18.X.1960, fl., H.S. Irwin (MG25882); Clevelândia, 3²4'S, $51^{\circ} 53^{\prime}$ W, 7.VIII.1960, fl., fr., H.S. Irwin (IAN47396). AMAZONAS: Manaus, 257'S, 5954'W, 20.III.2010, fl., N.C. Bigio \& M. Hopkins 102 (INPA, RON); Presidente Figueiredo, 203'S, 6003'W, 9.X.1997, fl., fr., M.G.G.Vieira et al. 1311 (INPA, MG). PARÁ: Porto Trombetas, 1²7'S, 56²2'W, 14.I.1991, fl., fr., O.H. Knowles 1675 (INPA).

Dalechampia pernambucensis Baill., Adansonia 5: 311. 1865. D. scandens var. pernambucensis (Baill.) Pax \& K. Hoffm., Das Pflanzenr. IV. 147 XII (Heft 68): 34. 1919. Type: BRASIL. Pernambuco: G. Gardner 1130 (lectotype G00434747!, designated by Armbruster and Webster 160: 1991; isolectotypes K000895663!, K000895664!, P00640236!).

Figure 10E-J; Figure 3G

Twining vine. Leaves simple, petiolar stipules 4-7 $\mathrm{mm}$ long, in pairs, persistent, lanceolate; petiole $2-7 \mathrm{~cm}$ long, sparsely pubescent; leaf blade, 3-lobed; lobes 3-5 × 4-11 cm, ovate to elliptical-ovate, base cordate, apex acute, margin sparsely serrate, adaxial and abaxial surfaces sparsely villous; membranaceous, venation actinodromous; primary veins $5-7$; stipels $2,1-3 \mathrm{~mm}$ long, lanceolate, persistent. Pseudanthium axillary, peduncle $3-5 \mathrm{~cm}$ long, pubescent to sparsely villous; involucral bracts $1-2.5 \times 1-2 \mathrm{~cm}$, greenish-white, ovate, adaxial and abaxial surfaces densely pubescent, apex deeply 3-lobed, lobes acute, base subcordate, margin fimbriate-ciliate, with stipitate-glandular trichomes; primary veins 5; bracteal stipule 4, 6-9 × 4-6 mm, deltoid. Staminate pleiochasium 7-flowered, peduncle ca. $2.5 \mathrm{~mm}$ long, sparsely pubescent; staminate bracteoles $2,7-8 \times$ ca. $5 \mathrm{~mm}$, reniform, connate, adaxial and abaxial surfaces pubescent; resiniferous gland 4-5 × 3.5-4 $\mathrm{mm}$ long, laminar. Staminate flowers, articulated pedicel ca. $1.5 \mathrm{~mm}$ long; pedicel ca. $2 \mathrm{~mm}$ long; sepals 4-5, 3-3.5 × 1-2 mm, oval-deltoid; stamens $4(-10)$, staminal tube $2-3 \mathrm{~mm}$ long, anthers bithecate, rimose. Pistillate cymule 3-flowered, peduncle ca. $1.5 \mathrm{~mm}$ long, pubescent; pistillate bracteoles $3,7-8 \times 3-5 \mathrm{~mm}$, reniform, connate, adaxial and abaxial surfaces pubescent, margin entire-ciliate. Pistillate flowers, pedicel 1-2 mm long; sepals 7-12, 1-2 × ca. $0.5 \mathrm{~mm}$, pinnatifid, margin 
hirsute, without stipitate-glandular trichomes, sparsely hirsute; ovary ca. $2 \mathrm{~mm}$ diam, pubescent; stylar column $8-9 \mathrm{~mm}$ long, linear, apex peltate to discoid. Capsule 5-7 mm diam, brown, sparsely pubescent, with small persistent pistillate sepals and stylar column. Seed ca. $3 \mathrm{~mm}$ diam, globose, smooth, brown with dark brown macules.

Distribution, habitat, and conservation status: Brazil (Webster \& Armbruster 1991). Occurs in the Northeast (Alagoas, Bahia, Ceará, Maranhão, Paraíba, Pernambuco) and North (Amazonas, Pará, Roraima; Figure 9A) regions (Pereira-Silva et al. 2020a, b, c). In the study area, it often grows in altered and open (abandoned fields) areas, in the “canopy," near sea level to $121 \mathrm{~m}$. According to IUCN (2019) criteria, the species is designated as Least Concern (LC), due to its EOO of $3,808,591.527 \mathrm{~km}^{2}$ (see Table 1).

Common Name: "urtiga-cipó"

Phenology: Flowers and fruits from March to December (Brazilian Amazon).

Taxonomic Notes: Dalechampia pernambucensis is often confused with $D$. scandens because both have simple, 3-lobed leaves and 3-lobed involucral bracts. However, D. pernambucensis has the following: stipels, lanceolate, persistent (vs. stipels, subulate, deciduous in $D$. scandens); peduncle pubescent to sparsely villous (vs. densely villous); involucral bracts ovate, greenish-white ( $v s$. broadly ovate, that vary from whitish to greenish), margins fimbriate-ciliate, with stipitate-glandular trichomes ( $v s$. margins serrate-ciliate, without or with sparse stipitateglandular trichomes); bracteal stipule deltoid, $4 \times 6 \mathrm{~mm}$ wide ( $v s$. lanceolate, ca. 1.5); staminate sepals 4-5, oval-deltoid ( $v s .4$, lanceolate); stamens $4(-10)$ (vs. ca. 50); pistillate bracteoles 2, 7-8 $\times 3-5 \mathrm{~mm}$ (vs. $3-4,3-5.5 \times 5.5-6 \mathrm{~mm})$; pistillate sepals pinnatifid, without stipitateglandular trichomes ( $v s$. pinnatisect, with stipitate-glandular trichomes), sparsely hirsute ( $v s$. densely hispid), and stylar column apex peltate to discoid (vs. crateriform).

Nomenclatural notes: Dalechampia pernambucensis was described by Baillon (1865) based on the specimen Gardner 1130 collected in Pernambuco. Webster \& Armbruster (1991) indicated that the holotype would be at G. However, Baillon did not specify the herbarium where it was deposited, when Webster \& Armbruster (1991) mentioned holotype, they did an inadvertent lectotypification, according to Art. 7.11 (Ex. 13) and Art. 9.10 (Ex. 11) of the ICN (Turland et al. 2018). In addition, we found one specimen at $\mathrm{P}$ that is $D$. pernambucensis isolectotype.

Selected Material: BRAZIL. AMAZONAS: estrada do Aleixo, $3^{\circ} 05^{\prime}$ S, 59 $55^{\prime}$ 'W, 16.XII.1974, fl., G.T. Prance \& A.E. Prance 20103 (INPA); Nhamundá, 002'S, 59³2'W, 5.VII.1975, fl., fr., S. Assumpção \& D. Coelho 43 (INPA). PARÁ: Marapanim, 053'S, 47³9'W, 30.VII.1958, fl., fr., P. Cavalcante 474 (INPA). RORAIMA: Boa Vista, $2^{\circ} 51^{\prime}$ S, $60^{\circ} 47^{\prime}$ W, 15.X.1977, fl., L. Coradin \& M. R. Cordeiro dos 678 (IAN, INPA).

Dalechampia scandens L., Gen. Sp. Plant.: 2: 1054. 1753. Type: ANTILHAS. Índias Ocidentais. Illustrated by Plumier, Plantarum Americanarum fasciculus 5: pl. 101 (Original illustration at P).

Figure 10K-P; Figure $3 \mathrm{H}$

Twining vine. Leaves simple, petiolar stipules $3-10 \mathrm{~mm}$ long, in pairs, persistent, lanceolate-ovate; petiole $2.5-10 \mathrm{~cm}$ long, densely pubescent; leaf blade, 3-lobed; lobes 2.5-14 × 3-6 cm, elliptical to oval, base cordate, apex acute, margin serrate to sparsely toothed, adaxial and abaxial surfaces sparsely villosous; membranaceous, venation actinodromous; primary veins $3-5$; stipels $2,1.5-3 \mathrm{~mm}$ long, subulate, deciduous. Pseudanthium axillary, peduncle $1.5-6 \mathrm{~cm}$ long, densely villous; involucral bracts $1.5-3 \times 1.6-3.5 \mathrm{~cm}$, broadly ovate, that vary from whitish to greenish, villous on adaxial and abaxial surfaces, apex 3-lobed, lobes acute, base truncate, margin serrate-ciliate, with or without sparse stipitate-glandular trichomes, primary veins 3-5; bracteal stipules $4,6-7 \times$ ca. $1.5 \mathrm{~mm}$, lanceolate. Staminate pleiochasium 7-10-flowered, peduncle 3-4 mm long, sparsely villous; staminate bracteoles $2,4-5 \times 7-8 \mathrm{~mm}$, oblong to broad-ovate, connate, adaxial and abaxial surfaces glabrous; resiniferous glands $2-3 \times 4-5 \mathrm{~mm}$, laminar. Staminate flowers, articulated pedicel 1-2 $\mathrm{mm}$ long; pedicel 1.5-2.5 mm long, sepals 4, 2.5-5 × ca. $1 \mathrm{~mm}$, lanceolate; stamens ca. 50, staminal tube ca. $1 \mathrm{~mm}$ long; anthers bithecate, rimose. Pistillate cymule 3-flowered, peduncle ca. $2 \mathrm{~mm}$, pubescent; pistillate bracteoles 3-4, 3-5.5 $\times 5.5-6 \mathrm{~mm}$, reniform, connate, adaxial and abaxial surfaces pubescent, margin entire-ciliate. Pistillate flowers, pedicel 1-2 mm long; sepals $8-12,6-8 \times 0.5-1.5 \mathrm{~mm}$, pinnatisect, margin hirsutous, with stipitate trichomes, densely hispid; ovary ca. $2 \mathrm{~mm}$ diam, pubescent; stylar column 5-7 mm long, greenish, linear, apex slightly crateriform. Capsule 3.5-4 mm diam, brown, sparsely pubescent, with small persistent pistillate sepals and stylar column. Seed $2.5-4 \mathrm{~mm}$ diam, globose, smooth, light brown with cream macules.

Distribution, habitat, and conservation status: From the Caribbean Islands (Cuba, Dominican Republic, Dominica, Haiti and Puerto Rico) to the Americas. In North America (United States, Mexico), Central (Belize, Costa Rica, El Salvador, Guatemala, Nicaragua), and South (Argentina, Bolivia, Brazil, Colombia, French Guiana, Guyana, Paraguay, Peru) (Webster \& Armbruster 1991). Found in the African continents (South Africa, Burkina Faso, Cabo Verde, Eswatini, Ethiopia, Kenya, Madagascar, Mayotte, Tanzania), and in Asia (India, Omã, United Arav Emiratos, Yemen). In Brazil, this species is widely distributed in the Northeast (Alagoas, Bahia, Ceará, Maranhão, Paraiba, Pernambuco, Rio Grande do Norte), Central-West (Mato Grosso do Sul, Mato Grosso), Southeast (Minas Gerais, São Paulo), and North (Amazonas, Pará, Rondônia, Roraima; Figure 9B) regions (PereiraSilva et al. 2020a, b, c). In the Brazilian Amazon, it is commonly found in altered secondary forests and savannah vegetation with sandy soil. According to IUCN (2019) criteria, the species is designated as Least Concern (LC), due to its EOO of 124,910,523.453 km² (see Table 1).

Phenology: Flowers and fruits from January to December (Brazilian Amazon).

Taxonomic Notes: In herbaria, Dalechampia scandens is commonly confused with $D$. pernambucensis. These species can be differentiated based on the characters in the comments under the latter species.

Selected Material: BRAZIL. AMAZONAS: Manaus, 2058'S, 600'W, 3.VIII.1955, fl., Chagas (MG21877); Paraná do Ramos, 2³8'S, 56³9'W, 27.III.1946, fl., fr., M.J. Pires \& G.A. Black 1200 (IAN). PARÁ: Itaituba, 4¹9'S, 56º3'W, 10.XI.1978, fr., M.G. Silva \& C. Rosário 3617 (MG); Almerim, 2º50'S, 60²8' W, 12.V.2005, fl., L.C.B. Lobato 3250 (MG). RONDÔNIA: rio machado, $8^{\circ} 04^{\prime} \mathrm{S}, 63^{\circ} 10^{\prime} \mathrm{W}$, I.1981, fl., fr., M. Goulding 1209 (MG). RORAIMA: Serra da Memória, 406'S, 60³7'W, 29.IV.1970, fl., I.A. Rodrigues et al. 721 (IAN).

Dalechampia sylvestris S. Moore, Trans. Linn. Soc. London, Bot., ser. 4, 2: 467. 1895. Type: BRASIL. MATO GROSSO: entre Santa Cruz e Tapirapuã, S. Moore 376 (holotype BM000947448!). 
MENDES, J.C.R. et al.

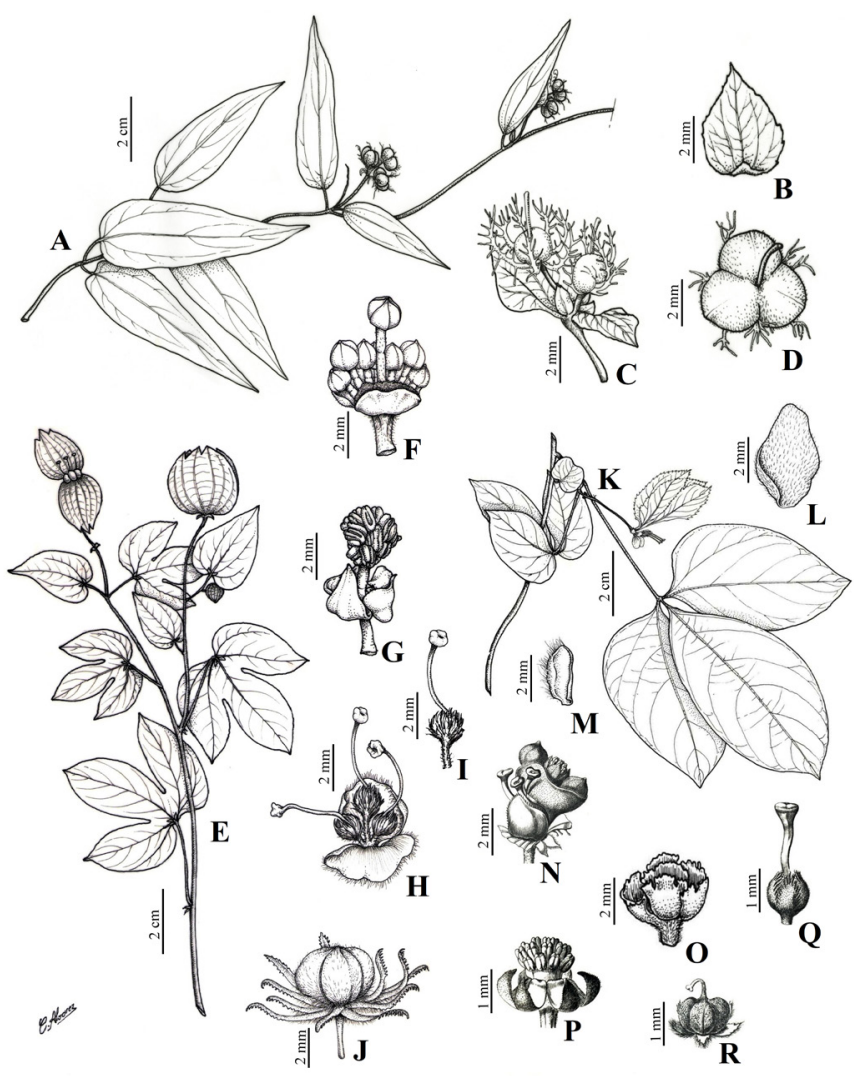

Figure 11 - A-D. Dalechampia tenuiramea - A. branch; B. involucral bract; C. fruits with involucral bracts and persistent pistillate sepals; D. fruit (Medeiros, $H$. et al. 802). E-J. D. tiliifolia - E. branch; F. staminate pleiochasium; G. staminate flower; H. pistillate cymule; I. pistillate flower; J. fruit with persistent involucral sepals and bracts (E, F, G, H, I. Mendes, J.C.R. et al. 61; J. Secco et al. 784). K-R. D. triphylla - K. branch; L. bracteal stipule; M. pistillate bracteoles; N. staminate pleiochasium and pistillate cymule; O. resiniferous gland; P. staminate flower; Q. pistillate flower; R. fruit (K-L Carvalho-Sobrinho, J.G. et al. 1145; M-O. Prance, G.T. et al. 10523; N, P, Q, R-adapted from Müll.Arg. 1874).

Figure 10Q-V; Figure 3I

Twining vine. Leaves compound, petiolar stipules 5-8 $\mathrm{mm}$ long, in pairs, persistent, lanceolate; petiole $1-5 \mathrm{~cm}$ long, hirsutous; leaf blade, 3-foliolate; middle leaflet $6.5-8.5 \times 2-3 \mathrm{~cm}$, elliptic, base attenuate, apex acute to acuminate; lateral leaflets $4.5-6 \times 2-3 \mathrm{~cm}$, oblique-ovate, apex attenuate; margin sparsely serrate-ciliate, adaxial surface slightly hirsutous, abaxial surface strigose, trichomes concentrated on the veins; membranaceous, venation eucamptodromous; primary veins 5; stipels $2,2-3 \mathrm{~mm}$ long, narrowly triangular, persistent. Pseudanthium axillary, peduncle $5.5-7.5 \mathrm{~cm}$ long; involucral bracts $3-5 \times 3.5-7.2 \mathrm{~cm}$, greenish-white, widely ovate, sparsely pubescent on adaxial and abaxial surfaces, apex 3-lobed, base truncate, margin serrate, primary veins 5; bracteal stipules 4, 3.5-4 cm long, lanceolate. Staminate pleiochasium 6-9-flowered, peduncle ca. $1.5 \mathrm{~mm}$ long, hispidous; staminate bracteoles $4,6.5-7 \times 5.5-6 \mathrm{~mm}$, deltoid, connate, adaxial surface glabrous, abaxial surface slightly tomentose; resiniferous glands $0.8-1 \times 0.5-0.8 \mathrm{~mm}$ long, fimbriate. Staminate flowers, articulated pedicel 3-7 $\mathrm{mm}$ long, sepals 4-6, 1.5-2 × 1-1.5 mm, ovate to lanceolate; stamens 10-25, staminal tube ca. $1 \mathrm{~mm}$ long; anthers bithecate, rimose. Pistillate cymule 3 -flowered, peduncle ca. $1.5 \mathrm{~mm}$ long, pubescent; pistillate bracteoles 1 , 4-4.5 mm long, ovate to deltoid, connate, adaxial and abaxial surfaces pubescent, margin entire-ciliate. Pistillate flowers, pedicel $0.8-1 \mathrm{~mm}$ long; sepals 6, 2-3.5 × ca. $1 \mathrm{~mm}$, entire, lanceolate; ovary ca. $1.5 \mathrm{~mm}$ diam, pubescent; stylar column $1-1.5 \mathrm{~cm}$ long, linear, apex slightly dilated-obovate. Capsule 1-2 mm diam, dark brown, sparsely pubescent, with small persistent pistillate sepals and stylar column. Seed ca. $2 \mathrm{~mm}$ in diam, subglobose, smooth, light brown with dark brown macules.

Distribution, habitat, and conservation status: Bolivia, Brazil, and Paraguay (Webster \& Armbruster 1991). In Brazil, it occurs in the Northeast (Bahia and Ceará), Central-West (Mato Grosso), Southeast (Minas Gerais), and North (Pará; Figure 9C) regions (Pereira-Silva et al. 2020a, b). In the Brazilian Amazon, it is found in roadside woods and on riverbanks. According to IUCN (2019) criteria, the species is designated as Least Concern (LC), due to its EOO of 3,161,012.045 $\mathrm{km}^{2}$ (see Table 1).

Phenology: Flowers and fruits from January to July (Brazilian Amazon).

Taxonomic Notes: Dalechampia sylvestris is characterized by its bracteal stipules that are $3.5-4 \mathrm{~cm}$ long, showy and lanceolate. It is similar to D. juruana, but can be differentiated based on the characters in the comments under this species.

Selected Material: BRAZIL. PARÁ: Marabá, 445'S, 5056'W, 30.III.1977, fl., M.G. Silva \& R. Bahia 2944 (MG, NY, RB); Parauapebas, 609'S, 4957'W, 2.VII.2010, fl., fr., A.J. Aruda et al. 326 (RB).

Dalechampia tenuiramea Müll. Arg., Linnaea 34: 222. 1865. Type: BRASIL. Amazonas: Borba, L. Riedel 22 (lectotype G00237309!, designated by Webster and Armbruster 164: 1991).

Figure 11A-D; Figure 3J

Twining vines. Leaves simple, petiolar stipules $2-2.5 \mathrm{~mm}$ long, in pairs, persistent, lanceolate, reflexed; petiole $1-2.5 \mathrm{~cm}$ long, pubescent; leaf blade, unlobed, 5-8 $\times 1.5-3 \mathrm{~cm}$, lanceolate-ovate, base slightly cordate, apex acuminate to slightly mucronate, margin slightly denticulate, adaxial and abaxial surfaces glabrous; membranaceous to subcoriaceous, venation campylodromous; primary veins 5; stipels 2, ca. $1 \mathrm{~mm}$ long, narrowly triangular, persistent. Pseudanthium axillary, peduncle $0.5-2 \mathrm{~cm}$ long; involucral bracts $1.5-2.5 \times 1-2 \mathrm{~cm}$, greenishwhite at anthesis, triangular-ovate, slightly hirsutous on adaxial and abaxial surfaces, apex acuminate, base cordate to subcordate, margin denticulate, primary veins 5 , bracteal stipules $4,1-1.5 \mathrm{~mm}$ long, lanceolate. Staminate pleiochasium 9-flowered; peduncle 1.5-2 mm long, pubescent; staminate bracteoles 4, 0.8-1.5 × 1-1.5 mm, truncate, connate, adaxial and abaxial surfaces pubescent; resiniferous glands 1.5-2 × 1-1.5 mm, laminar, with whitish resin. Staminate flowers, articulated pedicel ca. $1 \mathrm{~mm}$ long; pedicel $1 \mathrm{~mm}$ long; sepals 6, 1-1.5 $\times$ ca. $0.8 \mathrm{~mm}$, lanceolate; stamens ca. 20 , staminal tube ca. $1 \mathrm{~mm}$ long; anthers bithecate, rimose. Pistillate cymule 3 -flowered, peduncle ca. 1 $\mathrm{mm}$ long, pubescent; pistillate bracteoles 4, 1-2 × 0.8-1 mm, ovate to reniform, connate, adaxial and abaxial surfaces pubescent, margin entireciliate. Pistillate flowers, pedicel ca. $0.8 \mathrm{~mm}$ long; sepals 10-12, 1-1.2 $\times 0.8-1 \mathrm{~mm}$, pinnatisect-laciniate, with stipitate-glandular trichomes on the lobes; ovary ca. $2 \mathrm{~mm}$ diam, pubescent; stylar column 1-2 mm long, linear, apex obovate. Capsule 2.5-4 mm diam, light brown, hirsute, with small persistent pistillate sepals and stylar column. Seed $3.5 \mathrm{~mm}$ diam, globose, rugose, light brown with dark brown macules.

Distribution, habitat, and conservation status: Bolivia, and Brazil (Webster \& Armbruster 1991). In Brazil, it occurs in the Central-West (Mato Grosso) and North (Acre, Amapá, Amazonas, Pará, Rondônia; 
Figure 9D) regions (Pereira-Silva et al. 2020a). It is found in floodplain forests, on riverbanks, and in secondary forests. According to IUCN (2019) criteria, the species is designated as Near Threatened (NT), due to its EOO of 2,091,885.547 $\mathrm{km}^{2}$ (see Table 1). This species presents a relatively small area of occurrence (EOO) $\left(2,091 \mathrm{~km}^{2}\right)$ and because it is found in environments subject to constant anthropic actions, that have had a loss of original vegetation by erosion of rivers (e.g., Quendeque River [La Paz, Bolivia] and Iquiri River [Acre, Brazil]), if not controlled, could transfer the species to a risk category in the near future. Additionally, specimens were found in protected areas in Guajará-Mirim State Park in Rondônia. However, the Park has been suffering from deforestation after illegal logging and burning for pasture. Due to all these facts, $D$. tenuiramea is evaluated as Near Threatened (NT).

Phenology: Flowers and fruits from February to November (Brazilian Amazon).

Taxonomic Notes: Dalechampia tenuiramea is superficially similar to $D$. affinis, but can be distinguished by the following set of characters: involucral bracts greenish-white at anthesis (vs. white-cream), $<2.5$ cm long. (vs. $>3 \mathrm{~cm}$ long); resin whitish (vs. yellow resin); and stylar column apex obovate (vs. umbraculiform-dilated).

Selected Material: BRAZIL. ACRE: Rio Branco, 9²7'S, 7002'W, 8.II.1979, fl., fr., B.W. Albuquerque et al. 1337 (INPA, NY). AMAPÁ: Macapá, 003'S, 5106'W, 23.XI.1982, fl., fr., B. Rabelo \& Valda 1424 (MG). AMAZONAS: Humaitá, 6²16'S, 655'W, 4.VIII.1976, fl., F.N. Chagas et al. 183 (UEC). PARÁ: Faro, $2^{\circ} 10^{\prime}$ 'S, 56 $44^{\prime}$ 'W, 8.II.2017, fl., fr., J.C.R. Mendes 111 (MG). RONDÔNIA: Nova Mamoré, 10²7'S, 64²41'W, 11.V.2013, fl., fr., N.C. Bigio et al. 999 (INPA, MG, NY, RB, RON).

Dalechampia tiliifolia Lam., Encycl. 2: 257. 1786. Type: Without locality, possibly Peru, (holotype P [Herb. Jussieu, not found]).

Figure 11E-J; Figure 3K

Twining vine. Leaves simple, petiolar stipules 3-5.5 mm long, in pairs, deciduous, linear-lanceolate; petiole $3-10 \mathrm{~cm}$ long, pubescent; leaf blade: (a) unlobed (6-) 10-16 × (5-) 7-11 cm, oval, base cordate, apex acute, veins 5 at the base; (b) with one lateral lobed and (c) 3-lobed, 7-16 $\times 8-17 \mathrm{~cm}$, base cordate, oblong to obovate (median lobed), combining in the same individual, apex abruptly acute to acuminate, margin entire to slightly serrate, adaxial surface pubescent, abaxial surface sparsely pubescent; venation eucamptodromous; primary veins 5; stipels 2, 3-5 mm long, narrowly triangular, persistent. Pseudanthium axillary, peduncle 2-6 cm long; involucral bracts $3-6.5 \times 2.5-6 \mathrm{~cm}$, creamy white, ovate, densely pubescent on both surfaces, apex slightly 3 -lobed, base subcordate, margin serrate, primary veins 7 (-9); bracteal stipules 4, 2-3 mm long, lanceolate. Staminate pleiochasium 10-flowered; peduncle 4-8 mm long, pubescent, staminate bracteoles 4, 2.3-4 × 4-6 $\mathrm{mm}$, truncate, free, adaxial and abaxial surfaces pubescent; resiniferous glands 6-7 $\times 0.6-0.8 \mathrm{~mm}$, fimbriate, resin yellowish. Staminate flowers, articulated pedicel 4-5 $\mathrm{mm}$ long; pedicel $0.5-0.7 \mathrm{~mm}$ long, sepals 6 , 3-4 × 5-6 mm, lanceolate, base connate; stamens 16-40, staminal tube 3-4 cm long; anthers bithecate, rimose. Pistillate cymule 3-flowered, peduncle 1-4 mm long, pubescent, pistillate bracteoles 2, 6-7 × 1.5-9 $\mathrm{mm}$, deltoid, connate, adaxial and abaxial surfaces glabrous, margin ciliate. Pistillate flowers, pedicel $2-4 \mathrm{~mm}$ long, sparsely pubescent; sepals $10-12,2-4 \times 1-1.5 \mathrm{~mm}$, pinnatifid, with stipitate-glandular trichomes; ovary ca. $1.5 \mathrm{~mm}$ diam, villose-hispid, stylar column 6-12 $\mathrm{mm}$ long, linear, greenish, apex campanulate-dilated. Capsule $11 \mathrm{~mm}$ diam, verruculose, hirsutous-hispid, with small persistent pistillate sepals and stylar column. Seeds $5 \mathrm{~mm}$ diam, globose, smooth, light brown with discreetly cream macules.

Distribution, habitat, and conservation status: In the Caribbean Islands (Trinidad and Tobago), and the Americas. In North America (southern Mexico), Central America (Belize, Costa Rica, Guatemala, Honduras, Nicaragua, Panama), and South America (Bolivia, Brazil, Colombia, French Guiana, Guyana, Peru, Venezuela). In Brazil, it occurs in the North (Amapá, Amazonas, Pará, Rondônia, Roraima; Figure 9E), Northeast (Alagoas, Bahia, Ceará, Maranhão, Pernambuco, Piauí, Sergipe) and Central-West (Goiás, Mato Grosso) regions (Pereira-Silva $2020 \mathrm{a}, \mathrm{b}, \mathrm{c})$. It occurs in anthropic areas, in meadow environments, and tropical and seasonal forests. According to IUCN (2019) criteria, the species is designated as Least Concern (LC), due to its EOO of 16,304,443.697 $\mathrm{km}^{2}$ (see Table 1).

Phenology: Flowers and fruits from February to October (Brazilian Amazon).

Taxonomic Notes: Dalechampia tiliifolia can be confused with $D$. affinis and D. brownsbergensis. However, they can be differentiated using the aspects mentioned under the comments of these species. Specimens of D. tiliifolia have a peculiar morphology compared to other Amazonian species, due to the leaf polymorphism of three types on the same individual: (a) unlobed; (b) with a lateral lobe and (c) 3-lobed. In addition, polymorphic leaf blades also occur in D. hastata, which has leaves that are always unlobed, lanceolate, and usually with 2-3 lateral lobes on the same individual.

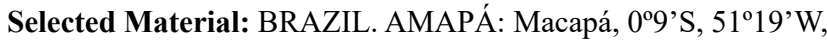
26.III.2001, fl., L.A. Pereira \& J.P. Reis 363 (IAN, INPA, MG). AMAZONAS: Maués, $4^{\circ} 45^{\prime} \mathrm{S}, 5^{\circ} 55^{\prime} \mathrm{W}, 14 . \mathrm{VII} .1983$, fr., C.A. Cid 4161 (INPA). PARÁ: Acará, 158'S, 48¹0'W, 9.VI.2014, fl., fr., J.C.R. Mendes et al. 61 (IAN, MG). RORAIMA: Caracaraí, 1³9'S, 61²0'W, 19.I. 2011, fl., fr., F.N. Cabral et al. 351 (MG). RONDÔNIA: Porto Velho, 908'S, 64º3'W, 15.VII.2012, fl., N.C. Bigio 596 (RON).

Dalechampia triphylla Lam., Encyl. 2:258, 1786. Type: BRAZIL. J. Dombey (holotype P00674020! [Herb. Jussieu 16292]; isotype NY 00842379!).

Figure 11K-R; Figure 3L

Twining vine. Leaves compound, petiolar stipules 3-4 × 1-1.5 $\mathrm{mm}$, in pairs, persistent, triangular-lanceolate to ovate; petiole 4-10 $\mathrm{cm}$ long, pubescent; leaf blade, 3-foliolate; meddle leaflet $6.5-16 \times$ 1.5-3 cm, lanceolate, base attenuate, apex narrowly acute; lateral leaflets 5.5-6 × 1.5-2.8 cm, oblique-lanceolate, apex narrowly acute; margin serrate to sinuate, adaxial surface glabrous, adaxial surface slightly pubescent; membranaceous to the chartaceous, venation eucamptodromous; primary veins 5; stipels 2, lanceolate, 2-4 mm long, persistent. Pseudanthium axillary, peduncle $1.5-2.5 \mathrm{~cm}$ long; involucral bracts $1.2-1.8 \times 1.7-2.5 \mathrm{~cm}$, white, ovate, glabrous on adaxial surface, pubescent on abaxial surface, apex deeply 3-lobed, base truncate to subcordate, the base of each involucral bract has 1 or 2 bands of colleters, margin denticulate or serrate, primary veins 5 ; bracteal stipules $4,2-5$ $\mathrm{mm}$ long, lanceolate. Staminate pleiochasium 10-22-flowered; peduncle ca. $1.5 \mathrm{~mm}$ long, sparsely pubescent; staminate bracteoles 4, 2-3 $\times 1.5-2$ $\mathrm{mm}$, truncate, free, adaxial and abaxial surfaces glabrous; resiniferous glands $1.5-2 \times 2-2.5 \mathrm{~mm}$, laminar. Staminate flowers, articulated pedicel ca. $1.5 \mathrm{~mm}$ long; pedicel 1-2 mm long; sepals $4,1.5-2 \times$ ca. 
$0.8 \mathrm{~mm}$, ovate-lanceolate, stamens 20-22, staminal tube ca. $1 \mathrm{~mm}$ long; anthers bithecate, rimose. Pistillate cymule 3 -flowered, peduncle ca. 1.5 $\mathrm{mm}$ long, pubescent; pistillate bracteoles 3, 2-5 × 1.5-2 mm, ovate, connate, adaxial surface glabrous, abaxial surface hirsutous, margin entire-ciliate. Pistillate flowers, pedicel ca. $0.5 \mathrm{~mm}$ long, subsessile; sepals $6-10,0.8-1 \times 1-2 \mathrm{~mm}$, free, pinnatisect-laciniate, densely pubescent, without stipitate-glandular trichomes; ovary ca. $1.5 \mathrm{~mm}$ diam, pubescent; stylar column 4-5 mm long, apex dilated-truncate. Capsule 8-9 mm diam, brown-lilac, glabrous, with small persistent pistillate sepals and stylar column. Seed 3-4 mm diam, globose, smooth, gray-brown with brown macules.

Distribution, habitat, and conservation status: Brazil, Guyana, Paraguay [new occurrence], and Suriname (Webster \& Armbruster 1991; Gillespie \& Armbruster 1997). In Brazil, it occurs in the Northeast (Bahia, Pernambuco), Southeast (Espírito Santo, Minas Gerais, Rio de Janeiro, São Paulo) and North (Amazonas, Roraima; Figure 9F) regions (Pereira-Silva et al. 2020a, b, c). In the Brazilian Amazon, it is found in tropical and subtropical seasonal forests. According to IUCN (2019) criteria, the species is designated as Least Concern (LC), due to its EOO of 7,393,743.928 $\mathrm{km}^{2}$ (see Table 1).

Phenology: Flowers and fruits from February to December (Brazilian Amazon).

Taxonomic Notes: Dalechampia triphylla is morphologically similar to $D$. cissifolia. These species can be distinguished using the characters mentioned in the comments under the latter species. We emphasize, a diagnostic characteristic in this species that is the presence of colleters at the base of involucral bracts.

Examined Material: BRAZIL. AMAZONAS: Presidente Figueiredo, $1^{\circ} 00^{\prime}$ S, 5900'W, 23.XI.2006, fl., J.G. Carvalho-Sobrinho et al. 1145 (INPA). RORAIMA: Near Maitá Indian Village, 3²0'S, 6324'W, 14.II.1971, fl., fr., G.T. Prance et al. 10523 (IAN, NY).

\section{Discussion}

This study documents 23 species of Dalechampia in the Brazilian Amazon, which are distributed in five sections: $D$. sect. Cremophyllum (Scheidw.) Baill. (D. magnoliifolia); D. sect. Dalechampia L. (D. brownsbergensis, D. cissifolia, D. pernambucensis, D. scandens, D. tenuiramea, D. triphylla); D. sect. Dioscoreifoliae Pax and Hoffm. (D. cujabensis, D. dioscoreifolia, D. juruana, D. megacarpa, D. sylvestris); D. sect. Rhopalostylis Pax and Hoffm. (D. attenuistylus, $D$. fragrans, D. gentryi, D. hastata, D. heterobractea, D. liesneri, D. micrantha, D. olympiana, D. parvibracteata); and D. sect. Tiliifoliae G.L. Webster \& Armbr. (D. affinis, D. tiliifolia). Of the seven sections proposed by Webster \& Armbruster (1991) and Armbruster (1996), there are no species of $D$. sect. Coriaceae Pax and K. Hoffm. and D. sect. Brevicolumnae in the region. Dalechampia sect. Rhopalostylis has species that are mostly exclusive to Amazonia Brazil or outside of Brazil. It is one of the most distinct and enigmatic sections because its species have flowers in pseudanthium without involucral bracts and resiniferous glands, characteristics opposite of the typical morphological patterns of the genus (Armbruster 1996).

Based on Prance (1988), Dalechampia species can be grouped into three distribution patterns: 1) widely distributed species (D. affinis, D. dioscoreifolia, D. pernambucensis, D. scandens, D. sylvestris, D. tenuiramea, D. tiliifolia, D. triphylla), with distributions beyond the Amazon biome, reaching the Cerrado and Atlantic Forest; 2) species with restricted distributions (D. attenuistylus, D. brownsbergensis, $D$. cissifolia, D. cujabensis, $D$. fragrans, $D$. gentry, D. heterobractea, $D$. juruana, D. liesneri, D. magnoliifolia, D. megacarpa, D. micrantha, D. olympiana, and D. parvibracteata), with distributions restricted to the Amazon and extra-Brazilian biomes; and 3) endemic species ( $D$. hastata), with records from the states of Amazonas, and Pará, in the secondary forests (capoeira). In this study, we point out the states of Amazonas and Pará as a center of distribution of these species, which can be found in various habitats.

In order to update the species of Dalechampia for the Flora of Brazil 2020 (Pereira-Silva et al. 2020a), we indicate that six species mentioned in the literature do not occur in this region: D. bangii Pax \& K. Hoffm., D. convolvuloides Lam., D. cordata Ruiz ex Pax \& K. Hoffm., D. fernandesii G.L. Webster, D. linearis Baill., and D. weddelliana Baill. Dalechampia bangii and D. cordata do not occur in Brazil, and the remaining species $(D$. fernandesii, $D$. linearis, and $D$. weddelliana) only occur in other Brazilian phytogeographic domains (Cerrado, Caatinga and Atlantic Forest), which were cited erroneously on the Lista da Flora do Brasil 2020 (BFG 2015) and have already been updated on the site. The occurrence of D. convolvuloides (see D.C. Daly 8522, barcode NY00540806!) in the state of Acre-Brazil, cited by Daly \& Silveira (2008), suggests that there is a type-collection of the species. However, we decided to keep it as a doubtful taxon as its precise identification requires a more detailed analysis, which we are going to perform and publicize in the very near future.

We affirm that this Red List of Dalechampia species occurring in the Brazilian Amazon provided for the first time a database of the conservation status of the species in their range of distribution with the majority occurring in South American countries, mainly in Bolivia, Brazil, Colombia, Ecuador, French Guiana, Guyana, Peru, Suriname, and Venezuela (see Supplementary Table 2). Therefore, it is expected to stimulate research and field expeditions in common areas or, even, in never collected areas in the Brazilian and extra-Brazilian Amazon, seeking to learn more about the biology of species with Deficient Data (DD), Endangered (EN), and Nearly Threatened (NT).

\section{Supplementary Material}

The following online material is available for this article:

Appendix 1 - List of material examined

Table 2 - Global distribution of species occurring in the Brazilian Amazon, as a subsidy for the calculation of conservation status (EOO and AOO).

\section{Author Contributions}

Jone Clebson Ribeiro Mendes: Data collection; species identification; data analysis and interpretation; preparation of manuscript and study design.

Alessandro Silva do Rosário: Data interpretation; species identification; preparation of the manuscript and critical review, adding intellectual content. 
Narcísio C. Bigio: Contribution to data collection; Interpretation of data; species identification; preparation of the manuscript and critical review, adding intellectual content.

Rafaela Alves Perira-Silva: Substantial contribution to the concept and design of the study; Contribution to data analysis and interpretation; Contribution to critical review, adding intellectual content.

Ricardo de S. Secco: Data collection; manuscript preparation and critical review, adding intellectual content; and study design.

\section{Conflicts of Interest}

The authors declare that they have no conflict of interest related to the publication of this manuscript.

\section{References}

ARMBRUSTER, W.S. 1996. Cladistic Analysis and Revision of Dalechampia sections Rhopalostylis and Brevicolumnae (Euphorbiaceae). Syst Bot 21(2): 209-235. https://doi.org/10.2307/2419748

ARMBRUSTER, W.S. 1999. Dalechampia. In Berry PE and collab. Flora of the Venezuelan Guayana, Missouri Bot. Gard. Press 5: 72-228.

ARMBRUSTER, W.S. \& WEBSTER, G.L. 1979. Pollination of two species of Dalechampia (Euphorbiaceae) in Mexico by euglossine bees. Biotropica 11: $278-283$.

ARMBRUSTER, W.S. \& BALDWIN, B.G. 1998. Switch from specialized to generalized pollination. Nature 394: 632.

ARMBRUSTER, W.S. \& STEINER, K.E. 1992. Pollination Ecology of Four Dalechampia Species (Euphorbiaceae) in Northern Natal, South Africa. Am. J. Bot. 79(3): 306-313. https://doi.org/10.2307/2445020

ANTONELLI, A., ZIZKA, A., CARVALHO, F.A., SCHARN, R., BACON, C.D., SILVESTRO, D. \& CONDAMINE, F.L. 2018. Amazonia is the primary source of Neotropical biodiversity. PNAS 115: 6034-6039.

ATHIÊ-SOUZA, S.M., PEREIRA-SILVA, R.A., SALES, M.F. \& ARMBRUSTER, W.S. 2019. Nomenclatural update of Dalechampia sect. Dioscoreifoliae (Euphorbiaceae). Kew Bulletin 74: 44. https://doi. org/10.1007/s12225-019-9820-7

BACHMAN, S., MOAT, J., HILL, A.W., DE LA TORRE, J. \& SCOTT, B. 2011. Supporting Red List threat assessments with GeoCAT: geospatial conservation assessment tool. ZooKeys 150: 117-126.

BAILLON, H. 1858. Étude Générale du Groupe des Euphorbiacées. Paris: Masson.

BAILLON, H. 1865. Euphorbiacées Americaines. Adansonia 5: 305-360.

BECKER, B.K. 2004. Amazônia. Geopolítica na virada do III Milênio. Rio de Janeiro. Garamond Universitária. 172 p, il.

BFG - The Brazil Flora Group. 2015. Growing knowledge: an overview of Seed Plant diversity in Brazil. Rodriguésia 66(4): 1085-1113.

DALY, D.C., SILVEIRA, M. 2008. Primeiro catálogo da Flora do Acre, Brasil. EDUFAC, Rio Branco, AC, $555 \mathrm{pp}$.

DUCKE, A. \& BLACK, G.A. 1954. Notas sobre a fitogeografia da Amazônia brasileira. Boletim Técnico do Instituto Agronômico do Norte 29: 1-62.

GILLESPIE, L.J. \& AMBRUSTER, W.S. 1997. A contribution to the Guianan Flora: Dalechampia, Haematostemon, Omphalea, Pera, Plukenetia and Tragia (Euphorbiaceae) with notes on subfamily Acalyphoideae. Smithson. contrib. bot. 86: 1-48. https://doi.org/10.5962/bhl.title.103726

HARRIS, J.G. \& HARRIS, M.W. 2001. Plant identification terminology: an illustrated glossary. Spring Lake, Utah. 216p.

HUBBELL, S.P., FANGLIANG, H., CONDIT, R., BORDA-DE-ÁGUA, L., KELLNER, J. \& ter STEEGE, H. 2008. How many tree species are there in the Amazon and how many of them will go extinct? Proc. Natl. Acad. Sci. U.S.A. 105: 11498-11504.
IBGE - Instituto Brasileiro de Geografia e Estatística. 2004. Mapa de Biomas e Vegetação. Available from: https://www.ibge.gov.br/geociencias/cartas-emapas/informacoes $=\& \mathrm{t}=$ downloads (last acess 10/04/2021)

IUCN. 2019. Guidelines for Using the IUCN Red List Categories and Criteria. Version 14. Prepared by the Standards and Petitions Subcommittee. Available from: http://cmsdocs.s3.amazonaws.com/RedListGuidelines.pdf(last acess 6/04/2021)

MAIA, W.C.R., EMMERICH, M. \& VALLE, L.S. 2002. Dalechampia Plum. Ex L. (Euphorbiaceae- Taxonomia das espécies ocorrentes nas restingas do Estado do Rio de Janeiro, Brasil. Boletim do Museu Nacional 119: 1-29.

MMA - Ministério do Meio Ambiente. 2021. Amazônia. Available from: https:// antigo.mma.gov.br/biomas/amaz\%C3\%B4nia.html (last acess 6/04/2021)

MENDES, J.C.R., SECCO, R.S., BIGIO, N.C. \& ROSÁRIO, A.S. 2019. Lectotypifications, new synonyms and new occurrences of Dalechampia L. (Euphorbiaceae) in Brazil. Phytotaxa 415(4): 189-198. http://dx.doi. org/10.11646/phytotaxa.415.4.3

MORI, A.S., SILVA, L.A.M., LISBOA, G. \& CORANDIN, L. 1989. Manual de Manejo do Herbário Fanerogâmico. Centro de Pesquisas do Cacau, Ilhéus. 103p.

MÜLLER, J. 1866. Euphorbiaceae. In: De Candole (Ed.) Prodr. (DC.) 15(2): 189-1261.

MÜLLER, J. 1874. Euphorbiaceae, Dalechampieae. In: Von Martius, Flora Brasiliensis 11(2): 633-664.

PAX, F. \& HOFFMANN, K. 1919. Euphorbiaceae - Dalechampia. In: Engler, A. (ed.), Das Pflanzenreich. IV - 147. XII (Heft 68): pp 1-59.

PEREIRA-SILVA, R.A., ATHIÊ-SOUZA, S.M., SECCO, R.S., MELO, A.L. \& SALES, M.F. 2016. Dalechampia erythrostyla (Euphorbiaceae), a new species from Northeastern Brazil. Syst Bot 41(4): 989-995. https://doi. org/10.1600/036364416X694116

PEREIRA-SILVA, R.A., ATHIÊ-SOUZA, S.M., LAURÊNIO, A.M. \& ARMBRUSTER, W.S. 2019. Dalechampia margarethiae (Euphorbiaceae), a New Species from Southeastern Brazil. Syst Bot 44: 832-837. https://doi. org/10.1600/036364419X15710776741350

PEREIRA-SILVA, R.A., OLIVEIRA, J.C.P., MENDES, J.C.R., BIGIO, N.C., SECCO, R.S., GAMA, B.R.A., SILVA, D.F., LEAL, B.A., MELO, A.L., ATHIÊSOUZA, S.M., SALES, M.F., CORDEIRO, W.P.F.S. 2020a. Dalechampia in Flora do Brasil 2020. Jardim Botânico do Rio de Janeiro. Available in: http:// floradobrasil.jbrj.gov.br/reflora/floradobrasil/FB17549. (last acess 6/01/2021)

PEREIRA-SILVA, R.A., GAMA, B.R.A., ATHIÊ-SOUZA, S.M., MELO, A.L., SALES, M.F. 2020b. Dalechampia (Euphorbiaceae, Acalyphoideae): synopsis of species from Northeast Brazil. Biota Neotropica 20(2): e20190805. https://doi.org/10.1590/1676-0611-BN-2019-0805

PEREIRA-SILVA, R.A., ATHIÊ-SOUZA, S.M., SECCO, R.S., MELO, A.L., SALES, M.F. 2020c. Dalechampia (Acalyphoideae, Euphorbiaceae) em Pernambuco. Rodriguésia 71: e03912017. http://dx.doi.org/10.1590/21757860202071071

PIRES, J.M. \& PRANCE, G.T. 1985. The vegetation types of the Brazilian Amazon. In Key Environments, Amazonia (G.T. Prance \& T.E. Levejoy, eds.). Pergamon Press, New York, p. 109-145.

PRANCE, G.T. 1978. The origin and evolution of the Amazon flora. Interciencia 3(4): 207-222.

PRANCE, G.T. 1988. Padrões de distribuição e especiação em Chrysobalanaceae e outras famílias de plantas amazônicas. Acta bot. bras. 1(2): 1-25. https:// doi.org/10.1590/S0102-33061987000300003

PRANCE, G.T. 1994. The use of phytogeographic data for conservation planning. In Systematics and Conservation evaluation (P.L. Forey, C.J. Humphries \& R.I. Vane-Wright, eds.). Clarendon Press, Oxford, p.145-163.

RADFORD, A.E., DICKISON, W.C., MASSEY, J.R. 1974. Vascular plant systematic. Harper \& Row Publishers, New York, 891p.

RODRIGUES, A.S. 2007. As tribos Dalechampieae Müll.Arg. e Manihoteae Melchior (Euphorbiaceae) no Distrito Federal. 115f. Dissertação (Pós Graduação em Botânica), Universidade de Brasília, Brasília, DF.

SÃO-THIAGO, O.S. \& VIEIRA, M.F. 2007. Sistema reprodutivo de Dalechampia aff. triphylla Lam. (Euphorbiaceae). R. Bras. Bioci. 5(1): 420-422. 
MENDES, J.C.R. et al.

SECCO, R.S., CORDEIRO, I., SENNA-VALE, L., SALES, M.F., LIMA, L.R., MEDEIROS, D., HAIAD, B.S., OLIVEIRA, A.S., CARUZO, M.B.R., CARNEIRO-TORRES, D. \& BIGIO, N.C. 2012. An overview of recent taxonomic studies on Euphorbiaceae s.l. in Brazil. Rodriguésia 63(1): 227-242. https://doi.org/10.1590/S2175-78602012000100014

SILVA, D.F., CORDEIRO, I. \& RITTER, M.R. 2020. Redescoberta de Dalechampia riparia L.B. Sm \& Downs (Euphorbiaceae), Espécie Endêmica de Santa Catarina, Brasil. Biodiversidade Brasileira 10(3): 3-10. https://doi. org/10.37002/biobrasil.v10i3.1638

SILMAN, M.R. 2007. Plant species diversity in Amazonian forests. In Tropical Rainforest Responses to Climatic Change (M.B. Bush \& J.R. Flenley, eds), Springer, Berlin, p.269-294.

STAFLEU, F.A. \& COWAN, R.S. 1976. Taxonomic literature. A selective guide to botanical publications and collections with dates, commentaries and types, 2ed, V I: A-G. Regnum vegetabile 94, Bohn, Scheltema \& Holkema, Utrecht: [I]-XL, 1-1136.

THIERS, B. 2020. [continuously updated] Index Herbarium. A global directory of herbaria and associated staff. New York Botanical Garden's Virtual Herbarium. Available in: http: sweetgum.nybg.org/ih/>. (last acess $05 / 03 / 2020$ )
WEBSTER, G.L. 1994. Classification of the Euphorbiaceae. Ann Mo Bot Gard 81: 3-32.

WEBSTER, G.L. 2014. Euphorbiaceae. In: The families and genera of Vascular Plants: Flowering Plants - Eudicots Malpighiales. Vol.XI, Springer.

WEBSTER, G.L. \& WEBSTER, B.D. 1972. The Morphology and Relationships of Dalechampia scandens (Euphorbiaceae). Am. J. Bot. 59 (6): 573-586. https://doi.org/10.2307/2441021

WEBSTER, G.L. \& AMBRUSTER, W.S. 1991. A synopsis of the neotropical species of Dalechampia (Euphorbiaceae). Bot. J. Linn. Soc. 94: 3-46. https:// doi.org/10.1111/j.1095-8339.1991.tb00202.x

WURDACK, K., HOFFMANN, P. \& CHASE, M.W. 2005. Molecular Phylogenetic analysis of the uniovulate Euphorbiaceae (Euphorbiaceae sensu stricto) using plastid $r b c L$ and $t r n L-F$ DNA sequences. Am. J. Bot. 92: 1397-1420. https://doi.org/10.3732/ajb.92.8.1397

Received: 02/04/2020

Accepted: 23/08/2021

Published online: 27/09/2021 